\title{
A Learning Health System Approach to the COVID-19 Pandemic: System-Wide Changes in Clinical Practice and 30-Day Mortality Among Hospitalized Patients
}

Authors: Erin K. McCreary PharmD ${ }^{1}$, Kevin E. Kip PhD², J. Ryan Bariola MD ${ }^{1}$, Mark Schmidhofer $\mathrm{MD}^{3}$, Tami Minnier MSN RN ${ }^{4}$, Katelyn Mayak $\mathrm{MS}^{5}$, Debbie Albin $\mathrm{BS}^{6}$, Jessica Daley PharmD ${ }^{6}$, Kelsey Linstrum MS ${ }^{7}$, Erik Hernandez PharmD ${ }^{8}$, Rachel Sackrowitz, MD Kailey Hughes ${ }^{1}$, Christopher Horvat MD ${ }^{9,}{ }^{10}$, Graham M. Snyder MD SM ${ }^{1}$, Bryan J. McVerry, $\mathrm{MD}^{11}$, Donald M. Yealy MD ${ }^{12}$, David T. Huang MD MPH ${ }^{9,12}$, Derek C. Angus MD MPH $\mathrm{FRCP}^{7,9}$, Oscar C. Marroquin $\mathrm{MD}^{2}$

1. Division of Infectious Diseases, Department of Medicine, University of Pittsburgh School of Medicine, Pittsburgh, PA, USA

2. Clinical Analytics, UPMC, Pittsburgh, PA, USA

3. Division of Cardiology, Dept of Medicine, University of Pittsburgh School of Medicine, Pittsburgh, PA, USA

4. UPMC Wolff Center and Quality Offices, UPMC, Pittsburgh, PA, USA

5. UPMC Communications, UPMC, Pittsburgh, PA, USA

6. UPMC Supply Chain Management/HC Pharmacy, UPMC, Pittsburgh, PA, USA

7. UPMC Office of Healthcare Innovation, Pittsburgh, PA, USA

8. Department of Pharmacy, UPMC Pinnacle, UPMC, Pittsburgh, PA, USA

9. Department of Critical Care Medicine, University of Pittsburgh School of Medicine, Pittsburgh, PA, USA

10. UPMC Children's Hospital of Pittsburgh, Pittsburgh, PA

11. Department of Medicine, Division of Pulmonary, Allergy, and Critical Care Medicine, Pittsburgh, PA, USA

12. Department of Emergency Medicine, University of Pittsburgh School of Medicine, Pittsburgh, PA, USA

Conflict of Interest Disclosure: None of the authors received any payments or influence from a third-party source for the work presented, and none report any potential conflicts of interest. 


\section{Corresponding Author:}

Kevin E. Kip, Ph.D.

Clinical Analytics, UPMC

200 Lothrop St, Forbes Tower FT9030

Pittsburgh, PA 15213

kipke2@upmc.edu

(412) 260-3753

\section{Acknowledgement:}

The authors thank the administrative and clinical staff of the UPMC COVID-19 Therapeutics Committee, including but not limited to: Allison Hydzik, Larry Hruska, Jennifer Dueweke, Robert Shulik, Amy Lukanski, Rozalyn Russell, Debra Rogers, Jesse Duff, Kevin Pruznak, Jennifer Zabala, Trudy Bloomquist, Daniel Gessel, LuAnn King, Jonya Brooks, Libby Shumaker, Betsy Tedesco, Sarah Sakaluk, Kathleen Flinn, Susan Spencer, Le Ann Kaltenbaugh, Michelle Adam, Meredith Axe, Melanie Pierce, Debra Masser, Theresa Murillo, Sherry Casali, Jim Krosse, Jeana Colella, Rebecca Medva, Jessica Fesz, Ashley Beyerl, Jodi Ayers, Hilary Maskiewicz, Mikaela Bortot, Amy Helmuth, Heather Schaeffer, Janice Dunsavage, Erik Hernandez, Ken Trimmer, Sheila Kruman, Teressa Polcha, Kevin Collins, Al L'Altrelli, Alex Viehman, Alyssa Lopus, Amy Dutko, Asmaa Debri, Brandon Smith, Brian Campfield, Bryan McVerry, Crystal Gilbert, Diana Pakstis, Elise Martin, Erin Weslander, Glenn Rapsinski, Janice Dunsavage, Jennifer Kozar, Jill Breton, John Goldman, Kailey Hughes, Kirk Jones, Krystina Zaradzki, Luis Urrutia, Marian Michaels, Matthew Partsch, Michael Donohoe, Minh-Hong Nguyen, Ricardo Arbulu Guerra, Stacey Miske, Thomas Hebert, Tina Khadem, Anthony Pizon, and their entire teams. We also thank the U.S. federal government and Pennsylvania Department of Health for the provision of remdesivir and monoclonal antibody treatment. 
medRxiv preprint doi: https://doi.org/10.1101/2021.08.26.21262661; this version posted August 28, 2021. The copyright holder for this preprint (which was not certified by peer review) is the author/funder, who has granted medRxiv a license to display the preprint in perpetuity.

It is made available under a CC-BY-ND 4.0 International license .

\begin{abstract}
Introduction: Rapid, continuous implementation of credible scientific findings and regulatory approvals is often slow in large, diverse health systems. The COVID-19 pandemic created a new threat to this common "slow to learn and adapt" model in healthcare. We describe how UPMC committed to a rapid learning health system (LHS) model to respond to the COVID19 pandemic.
\end{abstract}

Methods: An observational cohort study was conducted among 11,429 hospitalized patients from 22 hospitals (PA, NY) with a primary diagnosis of COVID-19 infection (March 19, 2020 - June 6, 2021). Sociodemographic and clinical data were captured from UPMC electronic medical record (EMR) systems. Patients were grouped into four time-defined patient "waves" based on nadir of daily hospital admissions, with wave 3 (September 20, 2020 - March 10, 2021) split at its zenith due to high volume with steep acceleration and deceleration. Outcomes included changes in clinical practice (e.g., use of corticosteroids, antivirals, and other therapies) in relation to timing of internal system analyses, scientific publications, and regulatory approvals, along with 30-day rate of mortality over time.

Results: Mean (SD) daily number of hospital admissions was 26 (28) with a maximum 7day moving average of 107 patients. System-wide implementation of the use of dexamethasone, remdesivir, and tocilizumab occurred within days of release of corresponding seminal publications and regulatory actions. After adjustment for differences in patient clinical profiles over time, each month of hospital admission was associated with an estimated $5 \%$ lower odds of 30-day mortality (adjusted OR $=0.95,95 \%$ confidence interval: $0.92-0.97, p<.001$ ).

Conclusions: In our large LHS, near real-time changes in clinical management of COVID-19 patients happened promptly as scientific publications and regulatory approvals 
medRxiv preprint doi: https://doi.org/10.1101/2021.08.26.21262661; this version posted August 28, 2021. The copyright holder for this preprint (which was not certified by peer review) is the author/funder, who has granted medRxiv a license to display the preprint in perpetuity. It is made available under a CC-BY-ND 4.0 International license .

occurred throughout the pandemic. Alongside these changes, patients with COVID-19 experienced lower adjusted 30-day mortality following hospital admission over time.

Keywords: Dexamethasone, remdesivir, tocilizumab, temporal trends, regulatory guidelines, scientific dissemination 
medRxiv preprint doi: https://doi.org/10.1101/2021.08.26.21262661; this version posted August 28, 2021. The copyright holder for this preprint (which was not certified by peer review) is the author/funder, who has granted medRxiv a license to display the preprint in perpetuity.

It is made available under a CC-BY-ND 4.0 International license .

\section{INTRODUCTION}

Integration of evidence-based practices is notoriously slow, especially at larger, diverse, health care systems. The emergence of a rapidly-spreading, severe respiratory virus pandemic created a heightened need for change in this common approach. ${ }^{1,2}$ Current research infrastructure and information technology systems facilitate unprecedented volume and speed of pandemicrelated information, and data sharing in the biomedical literature, social media, and other resources allow insights to flow much more quickly. ${ }^{3}$ Making efficient, optimal use of this massive, constantly changing information is paramount to minimize the deadly impact of the pandemic, and for the health and welfare of humanity at large.

In addition to the need for coordinated global approaches to pandemics, ${ }^{1}$ individual health care delivery systems must seek to give equitable, evidence-based care across institutions regardless of geographical region or hospital type. ${ }^{4}$ In this realm, a learning health system (LHS) is an ideal organizing principle to inform evidence-based responses to public health emergencies like COVID-19. The LHS concept is characterized as an environment in which "science, informatics, incentives, and culture are aligned for continuous improvement and innovation, with best practices seamlessly embedded in the delivery process and new knowledge captured as an integral by-product of the delivery experience." 5

Seeking to embrace the LHS model, the UPMC health system leveraged its science, data, and analytics capabilities and established the multidisciplinary COVID-19 Therapeutics Committee in early 2020. The purpose of this Committee was to evaluate any possible COVID19 treatment option and rapidly disseminate updated guidelines to all institutions within the system. The Committee also coordinated with information technology specialists to build forcing functions into several electronic medical records (EMRs) to enforce practice guideline 
medRxiv preprint doi: https://doi.org/10.1101/2021.08.26.21262661; this version posted August 28, 2021. The copyright holder for this preprint (which was not certified by peer review) is the author/funder, who has granted medRxiv a license to display the preprint in perpetuity.

It is made available under a CC-BY-ND 4.0 International license .

recommendations, and also collaborated with research teams to integrate clinical practice with clinical trial enrollment across the enterprise. This LHS process, coupled with regular internal COVID-19 analyses from the UPMC Clinical Analytics Team (described in Methods), formed the basis for establishing, disseminating, and documenting data-driven clinical recommendations to all UPMC outpatient and in-patient facilities caring for patients with COVID-19.

We describe the UPMC LHS approach to the COVID-19 pandemic since March 2020. We share processes on the development and dissemination of clinical guidelines that occurred in a near real-time manner across the entire UPMC system. We also share quantitative results of how such changes mirrored credible findings and information from key scientific publications and regulatory approvals. This is followed by temporal assessment of the 30-day rate of mortality of hospitalized patients with COVID-19.

\section{QUESTION OF INTEREST}

How have hospital patient volumes, patient clinical management, and 30-day mortality changed since the onset of the COVID-19 pandemic within a large, multi-hospital learning health system (LHS)?

\section{METHODS}

Sources of Data. We used data captured in the EMR and ancillary clinical systems, all of which are aggregated and harmonized in a Clinical Data Warehouse (CDW). UPMC is a 40hospital integrated academic healthcare system providing care principally within central and western Pennsylvania (USA). For the 22 hospitals with complete EMR data in the CDW, we accessed all key clinical data, including detailed sociodemographic and medical history data, 
medRxiv preprint doi: https://doi.org/10.1101/2021.08.26.21262661; this version posted August 28, 2021. The copyright holder for this preprint (which was not certified by peer review) is the author/funder, who has granted medRxiv a license to display the preprint in perpetuity.

It is made available under a CC-BY-ND 4.0 International license .

diagnostic and clinical tests conducted, surgical and other treatment procedures performed, prescriptions ordered, and billing charges on all outpatient and in-hospital encounters, with diagnoses and procedures coded based on the International Classification of Diseases, Ninth and Tenth revisions (ICD-9 and ICD-10, respectively).

Influence of UPMC COVID-19 Therapeutics Committee. We evaluated the influence of the UPMC COVID-19 Therapeutics Committee on change in COVID-19 clinical practice by time series plotting of the prevalence of in-hospital use of selected medications in relation to internal analyses and key scientific publications and regulatory approvals routinely reviewed by the committee. The UPMC COVID-19 Therapeutics Committee charge was to continuously evaluate evidence to create and disseminate treatment recommendations across the UPMC system. The process included: (1) weekly to bi-weekly review of internal analyses of COVID-19 patient testing, clinical practice, and outcomes generated from the CDW; (2) interim review of results from UPMC-led Randomized Embedded Multifactorial Adaptive Platform for COVID-19 (REMAP-COVID) trials, a global adaptive platform for trials of hospitalized and ambulatory patients with COVID-19; ${ }^{6,7}$ (3) weekly and ad-hoc review of key external scientific publications, press releases, and regulatory approvals of COVID-19 treatment approaches; (4) consensus determination of patient criteria and clinical instructions for use (and non-use) of established and emerging treatment approaches; (5) creation of EMR-embedded forcing functions to enforce therapeutics recommendations and guide prescribing at the point of care; (6) empowerment of local pharmacists to review and approve all COVID-19-related medications within the context of the guidelines; and (7) system-wide dissemination of continuously updated treatment recommendations using multimodal media sources. 
medRxiv preprint doi: https://doi.org/10.1101/2021.08.26.21262661; this version posted August 28, 2021. The copyright holder for this preprint (which was not certified by peer review) is the author/funder, who has granted medRxiv a license to display the preprint in perpetuity.

It is made available under a CC-BY-ND 4.0 International license .

The system-wide dissemination of treatment guidelines to all physicians and other clinicians affiliated with UPMC occurred through email notifications, computer screensavers, educational webinars, and formal directives from the chair of the Committee. A COVID-19 therapeutics webpage was built into the system intranet. The COVID-19 Therapeutics Committee also created continuous, updated recommendations on the use of monoclonal antibodies for ambulatory COVID-19 patients beginning in November 2020; however, the present analysis is restricted to treatment of hospitalized patients and omits that intervention.

Patient Population. We identified 323,101 patients with nucleic acid amplification tests for SARS-CoV-2 performed at a UPMC facility during the period March 17, 2020 to June 6, 2021. Of 53,183 patients (16.5\%) testing positive, 9,554 (18.0\%) were hospitalized at one of 22 UPMC hospitals. An additional 1,875 COVID-19 patients were hospitalized at a UPMC hospital with testing performed outside the UPMC system, resulting in a total of 11,429 hospitalized patients for analysis (Supplemental Figure S1).

Outcomes. We assessed changes in utilization of COVID-19 pharmacotherapy, level of oxygen support during hospitalization, and 30-day mortality from the index date of hospital admission. Pharmacotherapy and oxygen support were determined by the presence of charge codes within UPMC billing software. We assessed 30-day mortality by the hospital discharge disposition of "Ceased to Breathe" sourced from the inpatient Medical Record System, as well as deaths after discharge identified with the Death Master File (DMF) from the Social Security Administration (SSA)(NTIS 2021) as an external data source.

Explanatory Variables. For assessment of temporal changes, we categorized the study analysis period into 4 discrete "waves" based on empirical change in hospital admissions within the UPMC system. We chose the 4-wave classification scheme (Figure 1) based on the start and 
medRxiv preprint doi: https://doi.org/10.1101/2021.08.26.21262661; this version posted August 28, 2021. The copyright holder for this preprint (which was not certified by peer review) is the author/funder, who has granted medRxiv a license to display the preprint in perpetuity.

It is made available under a CC-BY-ND 4.0 International license .

nadir of individual waves. However, because Wave 3 (September 29, 2020 - March 10, 2021)

had dramatically higher hospital admissions and discharges, we split this wave at its zenith to assess its impact during rapid acceleration and deceleration. For assessment of variation between waves, we considered demographic variables, clinical history and medical comorbidities, laboratory values, vital signs, and medication use, with a focus on indicators of changing clinical practice such as use and timing of specific medications. We further assessed changes in COVID19 clinical practice by the date of important scientific and regulatory events, as formally reviewed by the UPMC COVID-19 Therapeutics Committee. We also assessed potential variation in clinical practice across the 22 hospitals by classification as "large academic" $(n=5)$, "large community" ( $n=8)$, or "small community" ( $n=9)$ (see Supplemental Table 1).

Statistical Methods. We describe changes over time in COVID-19 hospital admissions using 7-day moving mean and median values. We plotted temporal changes in pharmacotherapy used in-hospital on a weekly basis and anchored to important scientific and regulatory events. Medication use and oxygen support (proportion of patients) plots by wave of hospital admission were evaluated by the Cochran-Mantel-Haenszel test of trend. We compared presenting characteristics of hospitalized patients across the 4 waves using analysis of variance (ANOVA) or Wilcoxon tests for continuous variables (based on distributional properties) and chi-square tests for categorical variables. Crude rates of 30-day mortality for test positive and hospitalized patients by wave were censored at May 7, 2021 (i.e. to allow 30-day follow-up for all patients). A logistic regression model was fit using 30-day mortality as the dependent variable with stepwise selection of pre-treatment explanatory variables. Date of hospital admission was added to the model at the last stage to assess whether the odds of 30-day mortality changed over time after adjustment for different patient characteristics. We did not impute missing values in any 
medRxiv preprint doi: https://doi.org/10.1101/2021.08.26.21262661; this version posted August 28, 2021. The copyright holder for this preprint (which was not certified by peer review) is the author/funder, who has granted medRxiv a license to display the preprint in perpetuity.

It is made available under a CC-BY-ND 4.0 International license .

analyses. A two-sided type I error rate of 0.05 was used, and all analyses were conducted using the SAS System, Version 9.4 (SAS Institute, Cary, NC). We used The REporting of studies Conducted using Observational Routinely-collected health Data (RECORD) approach ${ }^{8}$ (see

Supplemental Table 2). Our study received formal ethics approval by the UPMC Ethics and Quality Improvement Review Committee (Project ID Project ID 2882).

\section{RESULTS}

Hospital Admissions. Over the 14+ month study period, the mean (SD) daily number of hospital admissions was 26 (28) with median of 17, IQR of 6-31, maximum 7-day moving mean of 107, and steep acceleration and deceleration during wave 3 from late September 2020 to early March 2021 (Figure 1). The mean hospital admission rate per day by wave was 4.0 (wave 1), 9.1 (wave 2), 46.1 (wave 3a), 48.0 (wave 3b), and 24.0 (wave 4).

Temporal Changes in Clinical Practice. Among patients who received any form of supplemental oxygen, there was rapid system-wide implementation in the use of dexamethasone immediately around the date in which initial positive results of the RECOVERY trial were published as a pre-print, ${ }^{9}$ (Figure 2). Of note, subsequent peer-review publication ${ }^{10}$ did not trigger an added uptake in use of dexamethasone. A steep increase in the use of remdesivir among patients on oxygen therapy occurred after Emergency Use Authorization (EUA) granted by the FDA $^{11}$ and subsequent public announcements and regulatory actions ${ }^{12-14}$ (Figure 3).

There was no appreciable variation in the use of dexamethasone or remdesivir by volume or type across the 22 UPMC hospitals (Supplemental Figures S2 and S3).

In contrast, despite widespread publicity ${ }^{15,16}$ our group recommended no role for hydroxychloroquine outside of the context of a clinical trial. Subsequently, in-hospital use was very low $(<6 \%)$ and did not vary over time, including after FDA EUA revocation of 
medRxiv preprint doi: https://doi.org/10.1101/2021.08.26.21262661; this version posted August 28, 2021. The copyright holder for this preprint (which was not certified by peer review) is the author/funder, who has granted medRxiv a license to display the preprint in perpetuity.

It is made available under a CC-BY-ND 4.0 International license .

hydroxychloroquine, ${ }^{17,18}$ and thus may be represented solely by patients taking this medication for a non-COVID-19 indication or enrolled in a clinical trial (Figure 4). More recently, an increase in the use of tocilizumab among eligible patients occurred immediately following preprint release of the REMAP-CAP trial results, ${ }^{19}$ (Figure 5) and a few weeks after publication of the RECOVERY ${ }^{20}$ and REMAP-CAP trial results ${ }^{21}$.

Among patients who received oxygen therapy, in-hospital use of corticosteroids was $80 \%$ or higher starting in wave 2. Two-thirds or more of all patients received steroids within 1 day of admission. Beginning in wave 3, about three-quarters of all clinically appropriate patients received remdesivir (almost always within 1 day of admission) (Supplemental Figure S4). Use of non-invasive ventilation did not vary appreciably across waves, whereas use of mechanical ventilation was markedly lower after wave 1 (Supplemental Figure S4).

Temporal Changes in Patient Characteristics and 30-Day Mortality. Hospitalized patients in waves 1 and 3a/3b were significantly older than patients in wave 2 (about 3-4 years), and the most recent wave 4 patients were the youngest with mean (median) age of 59.5 (62) years and about a quarter (27\%) being age 50 or younger (Supplemental Table 3). In aggregate, patients in waves 1 and 3 generally presented with more comorbidities, higher estimated 90-day probability of mortality, and higher neutrophil to lymphocyte ratio (NLR) and systemic inflammatory index than patients in waves 2 and 4 (Supplemental Table 3).

Among all test positive patients (hospitalized and not hospitalized), the 30-day mortality rate ranged from a high of $5.6 \%$ in wave 1 to a low of $2.2 \%$ in wave 4 (Table 2). Similar in direction, among hospitalized patients, the 30-day mortality rate ranged from a high of $19.8 \%$ in wave 1 to a low of $8.5 \%$ in wave 4 . Consistent with different risk profiles across the 4 waves, 30day mortality was highest in wave 1 , intermediate in wave 3 , and lowest in waves 2 and 4 . After 
medRxiv preprint doi: https://doi.org/10.1101/2021.08.26.21262661; this version posted August 28, 2021. The copyright holder for this preprint (which was not certified by peer review) is the author/funder, who has granted medRxiv a license to display the preprint in perpetuity.

It is made available under a CC-BY-ND 4.0 International license .

statistical adjustment, factors independently associated with 30-day mortality rate after hospitalization included older age (15\% increased odds per 5 years), male gender $(27 \%$ increased odds), estimated risk of mortality within 90 days after being hospitalized (12\% increased odds per 5 percentage points), and higher white blood cell, ALT, and NLRs (Table 3). Of note, adjusting for different risk profiles, each month of hospital admission to the UPMC system was associated with an estimated 5\% lower odds of 30-day mortality (adjusted OR $=0.95,95 \%$ confidence interval: $0.92-0.97, p<.001)$.

\section{DISCUSSION}

In 2009, the National Academy of Medicine (NAM) called for development of a learning health system (LHS), setting a goal that by 2020, “...90 percent of clinical decisions will be supported by accurate, timely, and up-to-date clinical information, and will reflect the best available evidence." 22 The importance of this LHS goal is emblematic with the COVID-19 pandemic. ${ }^{23}$ While lacking the ability to demonstrate cause and effect, the fact that the adjusted risk of in-hospital mortality among hospitalized COVID-19 patients at UPMC hospitals has decreased monthly by an average of $5 \%$ suggests a consistent learning effect to improved patient care. Additionally, there was no appreciable variation in type or volume of pharmacotherapy agents utilized for patients with COVID-19 across 22 hospitals, achieving the goal of equity and access regardless of patient zip code. Importantly, this model continues and can rapidly adapt as needed for SARS-CoV-2 variants, vaccination efforts, and other key variables.

In addition to continuous evaluation of UPMC internal analyses and controlled clinical trials, the COVID-19 Therapeutics Committee has evaluated the surge of COVID-19-related preprints and peer-reviewed publications that have emanated on an unprecedented scale 
throughout the pandemic. ${ }^{24,25,26}$ This placed a premium on expertise in evaluating the merits of published information. While our committee recognized the benefits of and thus implemented steroids, remdesivir, and tocilizumab in selected COVID-19 patients, it refuted use of hydroxychloroquine despite its EUA, given the existing data. ${ }^{27}$

The time between clinical evidence arising and uniform implementation of use was in days-to-weeks, rather than months-to-years, which has been the traditional gap for implementation of findings from RCTs into clinical practice. ${ }^{28,29,30} \mathrm{We}$ invested substantial efforts in the use of near-real time data and evidence (as per NAM LHS guidance), especially when the lack of available therapies fueled adoption of both warranted and unwarranted treatments. The average monthly risk-adjusted decrease in mortality of $5 \%$ observed in our healthcare system is noteworthy given the overall worse clinical profile of patients seen in wave 3. While utilization of pharmacotherapy is the focus of this analysis, it is likely that the observed improvements are multifactorial in nature. Alongside the Therapeutics Committee, an intensive care unit management group made real-time recommendations surrounding respiratory support strategies and other critical, supportive care and a systemwide infection prevention taskforce guided testing, tracing, isolation, and use of personal protective equipment. Accordingly, we posit there were changes of unmeasured practice patterns (i.e., ventilation strategies) learned over time that also contributed to the improved outcomes, and the rapid implementation of approved pharmacotherapies is a surrogate marker of systemwide learning. Lastly, while improvements in outcomes over time are natural to the progression of science and medical practice, the fact that the improvement seen in our healthcare system happened in a short time and mostly prior to mass vaccination, speaks, at least in part, to the importance of our system's embracing the organizational push to be an LHS. 
medRxiv preprint doi: https://doi.org/10.1101/2021.08.26.21262661; this version posted August 28, 2021. The copyright holder for this preprint (which was not certified by peer review) is the author/funder, who has granted medRxiv a license to display the preprint in perpetuity.

It is made available under a CC-BY-ND 4.0 International license .

While desirable, no formal criteria or certification process exist for an institution to be designated as an LHS. ${ }^{4}$ One component we believe is essential is embedding of randomized controlled trial procedures into routine care processes using existing institutional infrastructure and electronic health records. ${ }^{6}$ This approach defines broad eligibility criteria and aims to enroll as many "real-world" patients as possible to continuously evaluate therapies believed to be potentially efficacious. The key is avoiding "research" and "care" schisms, but rather use all care as an opportunity to learn about care improvement. Randomization is an added tool for some efforts, allowing adaptation as the trial evolves such that subjects are preferentially randomized to receive better performing arms based on interim analyses_-termed "response adaptive randomization."31 This was accomplished at our hospitals by embedding REMAP-CAP enrollment into the EMR, screening all patients with COVID-19 at all hospitals for trial eligibility, and integrating trial enrollment with Therapeutics Committee treatment guidelines. ${ }^{32}$

There are some limitations to our study; because this is the experience in one, albeit large, integrated healthcare system in Western Pennsylvania, the generalizability of our findings may be questioned. However, the fact that we saw similar findings across our different sites suggests that our findings are applicable across academic, community, and rural hospitals. In addition, we cannot determine the extent to which the therapeutic interventions implemented uniformly by the UPMC COVID-19 Therapeutics Committee contributed to lower adjusted mortality over time, as opposed to other less well documented clinical practices that may have been implemented over time (i.e., mechanical ventilation).

The LHS description and results presented herein are not meant to be content- or institution-specific, but rather to illustrate some of the processes that can be used to support the NAM imperative for clinical decisions that are supported by accurate, timely, and up-to-date 
clinical information that reflects the best available evidence. ${ }^{22}$ On a broader level, we support the stated advocacy for a learning health network that promotes collaboration among health systems, community-based organizations, and government agencies, especially during public health emergencies. $^{4}$

\section{CONCLUSION}

Other institutions have qualitatively described their respective LHS processes employed in response to the COVID-19 pandemic, ${ }^{33,34}$ with limited quantitative temporal assessment of clinical outcomes. ${ }^{35}$ We believe our analysis and description is the first to empirically document how COVID-specific processes employed within an LHS were actually implemented to achieve timely changes in clinical practice on a system level, which likely in turn favorably influenced clinical outcomes as evidenced by lower mortality over time. We recommend that institutions in describing their respective LHS do so by linking (and presenting) processes and sources of information that were used in the establishment and dissemination of clinical care guidelines with data-documented temporal changes in clinical practice and patient outcomes. 


\section{Figure Legends.}

\section{Figure 1.}

Plot of 7-day moving average of COVID-19 hospital admissions by empirically defined "waves" based on nadir and zenith (wave 3) of admissions. The time periods for the waves were as follows: Wave 1: - March 19 - June 16, 2020; Wave 2: June 17 - September 19, 2020; Wave

3a: September 20 - December 13, 2020; Wave 3b: December 14, 2020 - March 10, 2021; Wave 4: March 11 - June 6, 2021.

\section{Figure 2.}

Plot of weekly prevalence $(\%)$ of in-hospital use of dexamethasone among patients who received oxygen. On the x-axis, negative numbers reflect weeks prior to seminal event "A", the date (June $22,2020)$ in which preliminary results of the RECOVERY trial were published in Med Rxiv. Positive numbers reflect weeks after seminal event A.

\section{Figure 3.}

Plot of weekly prevalence $(\%)$ of in-hospital use of remdesivir among patients who received oxygen (but not mechanical ventilation after 10/20/2020). On the x-axis, negative numbers reflect weeks prior to seminal event "A", the date (May 1, 2020) in which the FDA issued Emergency Use Authorization (EUA) for remdesivir for patients hospitalized with severe COVID-19.

\section{Figure 4.}

Plot of weekly prevalence $(\%)$ of in-hospital use of hydroxychloroquine. On the $\mathrm{x}$-axis, negative numbers reflect weeks prior to seminal event "A", the date (March 28, 2020) in which the FDA granted EUA of hydroxychloroquine for COVID-19 patients. 
medRxiv preprint doi: https://doi.org/10.1101/2021.08.26.21262661; this version posted August 28, 2021. The copyright holder for this preprint (which was not certified by peer review) is the author/funder, who has granted medRxiv a license to display the preprint in perpetuity.

It is made available under a CC-BY-ND 4.0 International license .

\section{Figure 5.}

Plot of weekly prevalence $(\%)$ of in-hospital use of tocilizumab among patients who received high-flow nasal cannula (HFNC), BiPAP/CPAP (NIV), or mechanical ventilation (MV). On the $\mathrm{X}$-axis, negative numbers reflect weeks prior to seminal event " $\mathrm{A}$ ", the date (January 9, 2021) in which tocilizumab trial results were published among critically ill patients with COVID-19 who were receiving organ support.

\section{Supplemental Figure S1.}

Diagram of SARS-CoV-2 testing performed within the UPMC system, including COVID-19 hospitalized patients aggregated from patients tested within and outside of the UPMC system.

\section{Supplemental Figure S2.}

Plot of 4-week prevalence (\%) of in-hospital use of dexamethasone among patients who received oxygen by hospital classification. On the x-axis, negative numbers reflect weeks prior to seminal event "A", the date (June 22, 2020) in which preliminary results of the RECOVERY trial were published in Med Rxiv. Positive numbers reflect weeks after seminal event A.

\section{Supplemental Figure S3.}

Plot of 4-week prevalence $(\%)$ of in-hospital use of remdesivir among patients who received oxygen (but not mechanical ventilation after 10/20/2020) by hospital classification. On the xaxis, negative numbers reflect weeks prior to seminal event " $A$ ", the date (May 1, 2020) in which the FDA issued Emergency Use Authorization (EUA) for remdesivir for patients hospitalized with severe COVID-19.

\section{Supplemental Figure S4.}

Stacked bar charts $(100 \%)$ of the percentage of hospitalized patients treated with steroids (upper left), remdesivir (upper right), BiPAP/CPAP (lower left), and mechanical ventilation (lower 
right) by wave of hospital admission. For steroids, the denominator is patients on oxygen therapy. For Remdesivir, the denominator is patients on oxygen therapy and not mechanical ventilation after 10/20/2020. Light shading: treatment not used; intermediate shading: treated provided within 1 day of hospital admission; darker shading: treatment provided after the first day of hospital admission. P-values are based on the Cochran-Mantel-Haenszel test of trend. 
medRxiv preprint doi: https://doi.org/10.1101/2021.08.26.21262661; this version posted August 28, 2021. The copyright holder for this preprint (which was not certified by peer review) is the author/funder, who has granted medRxiv a license to display the preprint in perpetuity.

It is made available under a CC-BY-ND 4.0 International license .

\section{References}

1. Gates B. Innovation for pandemics. New England Journal of Medicine. 2018 May 31;378(22):2057-2060. doi: 10.1056/NEJMp1806283. PMID: 29847763.

2. Gates B. Responding to Covid-19 - A once-in-a-century pandemic? New England Journal of Medicine. 2020 Apr 30;382(18):1677-1679. doi: 10.1056/NEJMp2003762. Epub 2020 Feb 28. PMID: 32109012.

3. Hechenbleikner EM, Samarov DV, Lin E. Data explosion during COVID-19: A call for collaboration with the tech industry \& data scrutiny. EClinicalMedicine. 2020 May 24;23:100377. doi: 10.1016/j.eclinm.2020.100377. PMID: 32632412; PMCID: PMC7245577.

4. Romanelli RJ, Azar KMJ, Sudat S, Hung D, Frosch DL, Pressman AR. Learning health system in crisis: Lessons from the COVID-19 pandemic. Mayo Clin Proc Innov Qual Outcomes. 2021 Feb;5(1):171-176. doi: 10.1016/j.mayocpiqo.2020.10.004. Epub 2020 Oct 29. PMID: 33163894; PMCID: PMC7598312.

5. Institute of Medicine (US) Roundtable on Evidence-Based Medicine. The Learning Healthcare System: Workshop Summary. Olsen L, Aisner D, McGinnis JM, editors. Washington (DC): National Academies Press (US); 2007. PMID: 21452449.

6. UPMC REMAP-COVID Group, on behalf of the REMAP-CAP Investigators. Implementation of the Randomized Embedded Multifactorial Adaptive Platform for COVID-19 (REMAP-COVID) trial in a US health system-lessons learned and recommendations. Trials. 2021 Jan 28;22(1):100. doi: 10.1186/s13063-020-04997-6. Erratum in: Trials. 2021 Feb 16;22(1):145. PMID: 33509275; PMCID: PMC7841377. 
medRxiv preprint doi: https://doi.org/10.1101/2021.08.26.21262661; this version posted August 28, 2021. The copyright holder for this preprint (which was not certified by peer review) is the author/funder, who has granted medRxiv a license to display the preprint in perpetuity. It is made available under a CC-BY-ND 4.0 International license .

7. Huang DT, McCreary EK, Bariola JR, Wadas RJ, Kip KE, Marroquin OC, Koscumb S, Collins K, Shovel JA, Schmidhofer M, Wisniewski MK, Sullivan C, Yealy DM, Axe M, Nace DA, Haidar G, Khadem T, Linstrum K, Snyder GM, Seymour CW, Montgomery SK, McVerry BJ, Berry L, Berry S, Meyers R, Weissman A, Peck-Palmer OM, Wells A, Bart R, Albin DL, Minnier T, Angus DC. The UPMC OPTIMISE-C19 (OPtimizing Treatment and Impact of Monoclonal antIbodieS through Evaluation for COVID-19) trial: a structured summary of a study protocol for an open-label, pragmatic, comparative effectiveness platform trial with response-adaptive randomization. Trials. 2021 May 25;22(1):363. doi: 10.1186/s13063-021-05316-3. PMID: 34034784; PMCID: PMC8144687.

8. Benchimol EI, Smeeth L, Guttmann A, Harron K, Moher D, Petersen I, Sørensen HT, von Elm E, Langan SM; RECORD Working Committee. The REporting of studies Conducted using Observational Routinely-collected health Data (RECORD) statement. PLoS Med. 2015 Oct 6;12(10):e1001885. doi: 10.1371/journal.pmed.1001885. PMID: 26440803; PMCID: PMC4595218.

9. Horby P, Kim WS, Emberson J, Mafham M, Bell J, Linsell L,... RECOVERY Collaborative Group. Effect of dexamethasone in hospitalized patients with COVID-19preliminary report. MedRxiv 2020.06.22.20137273

doi: https://doi.org/10.1101/2020.06.22.20137273

10. RECOVERY Collaborative Group, Horby P, Lim WS, Emberson JR, Mafham M, Bell JL, Linsell L, Staplin N, Brightling C, Ustianowski A, Elmahi E, Prudon B, Green C, Felton T, Chadwick D, Rege K, Fegan C, Chappell LC, Faust SN, Jaki T, Jeffery K, Montgomery A, Rowan K, Juszczak E, Baillie JK, Haynes R, Landray MJ. 
medRxiv preprint doi: https://doi.org/10.1101/2021.08.26.21262661; this version posted August 28, 2021. The copyright holder for this preprint (which was not certified by peer review) is the author/funder, who has granted medRxiv a license to display the preprint in perpetuity.

It is made available under a CC-BY-ND 4.0 International license .

Dexamethasone in hospitalized patients with Covid-19. New England Journal of

Medicine. 2021 Feb 25;384(8):693-704. doi: 10.1056/NEJMoa2021436. Epub 2020 Jul

17. PMID: 32678530; PMCID: PMC7383595.

11. Food and Drug Administration (FDA). Coronavirus (COVID-19) Update: FDA Issues Emergency Use Authorization for Potential COVID-19 Treatment.

https://www.fda.gov/news-events/press-announcements/coronavirus-covid-19-updatefda-issues-emergency-use-authorization-potential-covid-19-treatment. May 1, 2020.

Accessed June 10, 2021.

12. Gilead Press Releases. Gilead Announces Results from Phase 3 Trial of Remdesivir in Patients with Moderate COVID-19. https://www.gilead.com/news-and-press/pressroom/press-releases/2020/6/gilead-announces-results-from-phase-3-trial-of-remdesivirin-patients-with-moderate-covid-19. June 1, 2020. Accessed June 10, 2021.

13. U.S. Health and Human Services. Trump Administration Secures New Supplies of Remdesivir for the United States.

https://public3.pagefreezer.com/browse/HHS\%20\%E2\%80\%93\%C2\%A0About\%20New s/20-01-2021T12:29/https://www.hhs.gov/about/news/2020/06/29/trump-administrationsecures-new-supplies-remdesivir-united-states.html. June 29, 2020. Accessed June 10, 2021.

14. U.S. Food and Drug Administration (FDA). FDA Approves First Treatment for COVID19. https://www.fda.gov/news-events/press-announcements/fda-approves-first-treatment$\underline{\text { covid- }}$

19\#: :text=Today\%2C\%20the\%20U.S.\%20Food\%20and,of\%20COVID\%2D19\%20requ iring\%20hospitalization. October 22, 2020. Accessed June 10, 2021 
medRxiv preprint doi: https://doi.org/10.1101/2021.08.26.21262661; this version posted August 28, 2021. The copyright holder for this preprint (which was not certified by peer review) is the author/funder, who has granted medRxiv a license to display the preprint in perpetuity.

It is made available under a CC-BY-ND 4.0 International license .

15. U.S. Food and Drug Administration (FDA). Request for Emergency Use Authorization for Use of Chloroquine Phosphate or Hydroxychloroquine Sulfate Supplied from the Strategic National Stockpile for Treatment of 2019 Coronavirus Disease.

https://www.fda.gov/media/136534/download. March 28, 2020. Accessed June 10, 2021.

16. Solender A. All the Times Trump Has Promoted Hydroxychloroquine. Forbes Magazine, May 22, 2020. https://www.forbes.com/sites/andrewsolender/2020/05/22/all-the-timestrump-promoted-hydroxychloroquine/?sh=6c6ba53b4643. Accessed June 10, 2021.

17. U.S. Food and Drug Administration (FDA). FDA cautions against use of hydroxychloroquine or chloroquine for COVID-19 outside of the hospital setting or a clinical trial due to risk of heart rhythm problems.

https://www.fda.gov/media/137250/download. April 24, 2020. Accessed June 10, 2021.

18. U.S. Food and Drug Administration (FDA). Memorandum Explaining Basis for Revocation of Emergency Use Authorization for Emergency Use of Chloroquine Phosphate and Hydroxychloroquine Sulfate.

https://www.fda.gov/media/138945/download. June 15, 2020. Accessed June 10, 2021.

19. The REMAP-CAP Investigators, _Gordon AC, Mouncey PR, Al-Beidh F, Rowan KM, Nichol AD, Arabi YM, et al. Interleukin-6 receptor antagonists in critically ill patients with Covid-19 - Preliminary report. MedRxiv 2021.01.09.2021. https://doi.org/10.1101/2021.01.07.21249390. January 9, 2021

20. Horby PW, Pessoa-Amorim G, Peto L, Brightling CE, Sarkar R, Thomas K, et al.: RECOVERY Collaborative Group. Tocilizumab in patients admitted to hospital with COVID-19 (RECOVERY): preliminary results of a randomised, controlled, open label 
medRxiv preprint doi: https://doi.org/10.1101/2021.08.26.21262661; this version posted August 28, 2021. The copyright holder for this preprint (which was not certified by peer review) is the author/funder, who has granted medRxiv a license to display the preprint in perpetuity.

It is made available under a CC-BY-ND 4.0 International license .

platform trial. MedRxiv 2021.02.11.21249528:

doi: https://doi.org/10.1101/2021.02.11.21249258

21. REMAP-CAP Investigators, Gordon AC, Mouncey PR, Al-Beidh F, Rowan KM, Nichol AD, Arabi YM, et al. Interleukin-6 receptor antagonists in critically ill patients with Covid-19. New England Journal of Medicine. 2021 Apr 22;384(16):1491-1502. doi: 10.1056/NEJMoa2100433. Epub 2021 Feb 25. PMID: 33631065; PMCID: PMC7953461.

22. Institute of Medicine (US) Roundtable on Evidence-Based Medicine. Leadership Commitments to Improve Value in Healthcare: Finding Common Ground: Workshop Summary. Washington (DC): National Academies Press (US); 2009. PMID: 21391347.

23. McGinnis JM, Fineberg HV, Dzau VJ. Advancing the Learning Health System. New England Journal of Medicine. 2021 Jul 1;385(1):1-5. doi: 10.1056/NEJMp2103872. Epub 2021 Jun 26. PMID: 34192452.

24. Kirkham JJ, Penfold NC, Murphy F, Boutron I, Ioannidis JP, Polka J, Moher D. Systematic examination of preprint platforms for use in the medical and biomedical sciences setting. BMJ Open. 2020 Dec 29;10(12):e041849. doi: 10.1136/bmjopen-2020041849. PMID: 33376175; PMCID: PMC7778769.

25. Bauchner H, Fontanarosa PB, Golub RM. Editorial evaluation and peer review during a pandemic: How journals maintain standards. JAMA. 2020 Aug 4;324(5):453-454. doi: 10.1001/jama.2020.11764. PMID: 32589195.

26. Park JJH, Mogg R, Smith GE, Nakimuli-Mpungu E, Jehan F, Rayner CR, Condo J, Decloedt EH, Nachega JB, Reis G, Mills EJ. How COVID-19 has fundamentally changed 
medRxiv preprint doi: https://doi.org/10.1101/2021.08.26.21262661; this version posted August 28, 2021. The copyright holder for this preprint (which was not certified by peer review) is the author/funder, who has granted medRxiv a license to display the preprint in perpetuity.

It is made available under a CC-BY-ND 4.0 International license.

clinical research in global health. Lancet Glob Health. 2021 May;9(5):e711-e720. doi: 10.1016/S2214-109X(20)30542-8. PMID: 33865476; PMCID: PMC8049590.

27. Alexander PE, Debono VB, Mammen MJ, Iorio A, Aryal K, Deng D, Brocard E, Alhazzani W. COVID-19 coronavirus research has overall low methodological quality thus far: case in point for chloroquine/hydroxychloroquine. J Clin Epidemiol. 2020 Jul;123:120-126. doi: 10.1016/j.jclinepi.2020.04.016. Epub 2020 Apr 21. PMID: 32330521; PMCID: PMC7194626.

28. Morris ZS, Wooding S, Grant J. The answer is 17 years, what is the question: understanding time lags in translational research. J R Soc Med. 2011 Dec;104(12):51020. doi: 10.1258/jrsm.2011.110180. PMID: 22179294; PMCID: PMC3241518.

29. Melnyk BM, Fineout-Overholt E, Gallagher-Ford L, Kaplan L. The state of evidencebased practice in US nurses: critical implications for nurse leaders and educators. Journal of Nursing Administration. 2012 Sep;42(9):410-7. doi:

10.1097/NNA.0b013e3182664e0a. PMID: 22922750.

30. Warren JI, McLaughlin M, Bardsley J, Eich J, Esche CA, Kropkowski L, Risch S. The strengths and challenges of implementing EBP in healthcare systems. Worldviews Evid Based Nurs. 2016 Feb;13(1):15-24. doi: 10.1111/wvn.12149. PMID: 26873372.

31. Saville BR, Berry SM. Balanced covariates with response adaptive randomization. Pharm Stat. 2017 May;16(3):210-217. doi: 10.1002/pst.1803. Epub 2017 Mar 6. PMID: 28261972.

32. Angus DC, Derde L, Al-Beidh F, Annane D, Arabi Y, Beane A, et al. Effect of hydrocortisone on mortality and organ support in patients with severe COVID-19: The REMAP-CAP COVID-19 Corticosteroid Domain Randomized Clinical Trial. JAMA. 
medRxiv preprint doi: https://doi.org/10.1101/2021.08.26.21262661; this version posted August 28, 2021. The copyright holder for this preprint (which was not certified by peer review) is the author/funder, who has granted medRxiv a license to display the preprint in perpetuity. It is made available under a CC-BY-ND 4.0 International license .

2020 Oct 6;324(13):1317-1329. doi: 10.1001/jama.2020.17022. PMID: 32876697;

PMCID: PMC7489418.

33. Beck AF, Hartley DM, Kahn RS, Taylor SC, Bishop E, Rich K, Saeed MS, Schuler CL, Seid M, Cronin SC, Raney L, Zafar MA, Margolis PA. Rapid, bottom-up design of a regional learning health system in response to COVID-19. Mayo Clin Proc. 2021 Apr;96(4):849-855. doi: 10.1016/j.mayocp.2021.02.006. Epub 2021 Feb 16. PMID: 33714596; PMCID: PMC7885665.

34. Khanna N, Klyushnenkova EN, Kaysin A, Stewart DL. Utilizing the learning health system adaptation to guide family medicine practice to COVID-19 response. J Prim Care Community Health. 2020 Jan-Dec;11:2150132720966409. doi:

10.1177/2150132720966409. PMID: 33063617; PMCID: PMC7580135.

35. Anesi GL, Jablonski J, Harhay MO, Atkins JH, Bajaj J, Baston C, et al. Characteristics, outcomes, and trends of patients with COVID-19-related critical illness at a learning health system in the United States. Ann Intern Med. 2021 May;174(5):613-621. doi: 10.7326/M20-5327. Epub 2021 Jan 19. PMID: 33460330; PMCID: PMC7901669. 
medRxiv preprint doi: https://doi.org/10.1101/2021.08.26.21262661; this version posted August 28, 2021. The copyright holder for this preprint (which was not certified by peer review) is the author/funder, who has granted medRxiv a license to display the preprint in perpetuity. It is made available under a CC-BY-ND 4.0 International license .

Table 1. Thirty-Day Mortality Rate of Test Positive and Hospitalized Cases by Wave

\begin{tabular}{cccccc}
\hline \multirow{2}{*}{ Wave } & Patient Time Period & All Test Positives & \multicolumn{2}{c}{ Hospitalized Cases } \\
& March 19 - June 16, 2020 & 1369 & 5.6 & 358 & 19.8 \\
\hline 1 & Rate (\%) & N & Rate (\%) \\
2 & June 17 - September 19, 2020 & 3926 & 2.5 & 859 & 10.1 \\
3a & September 20 - December 13, 2020 & 21471 & 2.8 & 3925 & 14.9 \\
3b & December 14, 2020 - March 10, 2021 & 18637 & 2.9 & 4174 & 13.0 \\
4 & March 11 - May 7, 2021 & 6378 & 2.2 & 1674 & 8.5 \\
\hline
\end{tabular}


medRxiv preprint doi: https://doi.org/10.1101/2021.08.26.21262661; this version posted August 28, 2021. The copyright holder for this preprint (which was not certified by peer review) is the author/funder, who has granted medRxiv a license to display the preprint in perpetuity.

It is made available under a CC-BY-ND 4.0 International license.

Table 2. Logistic Regression Analysis of Factors Associated with 30-Day Mortality (n=10,763

Hospitalized Patients)

\begin{tabular}{|c|c|c|c|c|}
\hline Factor & $\begin{array}{l}\text { Unadjusted } \\
\text { OR }\end{array}$ & $\begin{array}{l}\text { Adjusted } \\
\text { OR }\end{array}$ & $\begin{array}{c}95 \% \\
\text { CI }\end{array}$ & $\begin{array}{c}\text { p- } \\
\text { value }\end{array}$ \\
\hline Age (per 5 years) & 1.23 & 1.15 & $1.11-1.18$ & $<.001$ \\
\hline Male gender & 1.41 & 1.27 & $1.12-1.43$ & $<.001$ \\
\hline $\begin{array}{l}\text { Estimated risk of mortality within } 90 \text {-days after } \\
\text { being hospitalized (per } 5 \text { percentage points) }{ }^{\mathrm{a}}\end{array}$ & 1.17 & 1.12 & $1.10-1.14$ & $<.001$ \\
\hline Log white blood cell count at hospital admission & 1.98 & 1.52 & $1.36-1.70$ & $<.001$ \\
\hline $\begin{array}{l}\text { Log alanine aminotransferase (ALT) at hospital } \\
\text { admission }\end{array}$ & 1.25 & 1.42 & $1.30-1.54$ & $<.001$ \\
\hline Neutrophil to lymphocyte ratio (per quintile) & 1.24 & 1.19 & $1.15-1.24$ & $<.001$ \\
\hline Date of hospital admission (per month) & 0.95 & 0.95 & $0.92-0.97$ & $<.001$ \\
\hline
\end{tabular}

Model c statistic $=0.751$ based on 1,416 deaths. ${ }^{\text {a }}$ Risk score is derived from an internally validated algorithm that is comprised of a range of variables predictive of mortality including socio-demographics, medical history, recent laboratory values, and prior health care utilization. 
Daily Hospital Admissions

120.0

Hospital Admissions (7-day moving average)

Figure 1

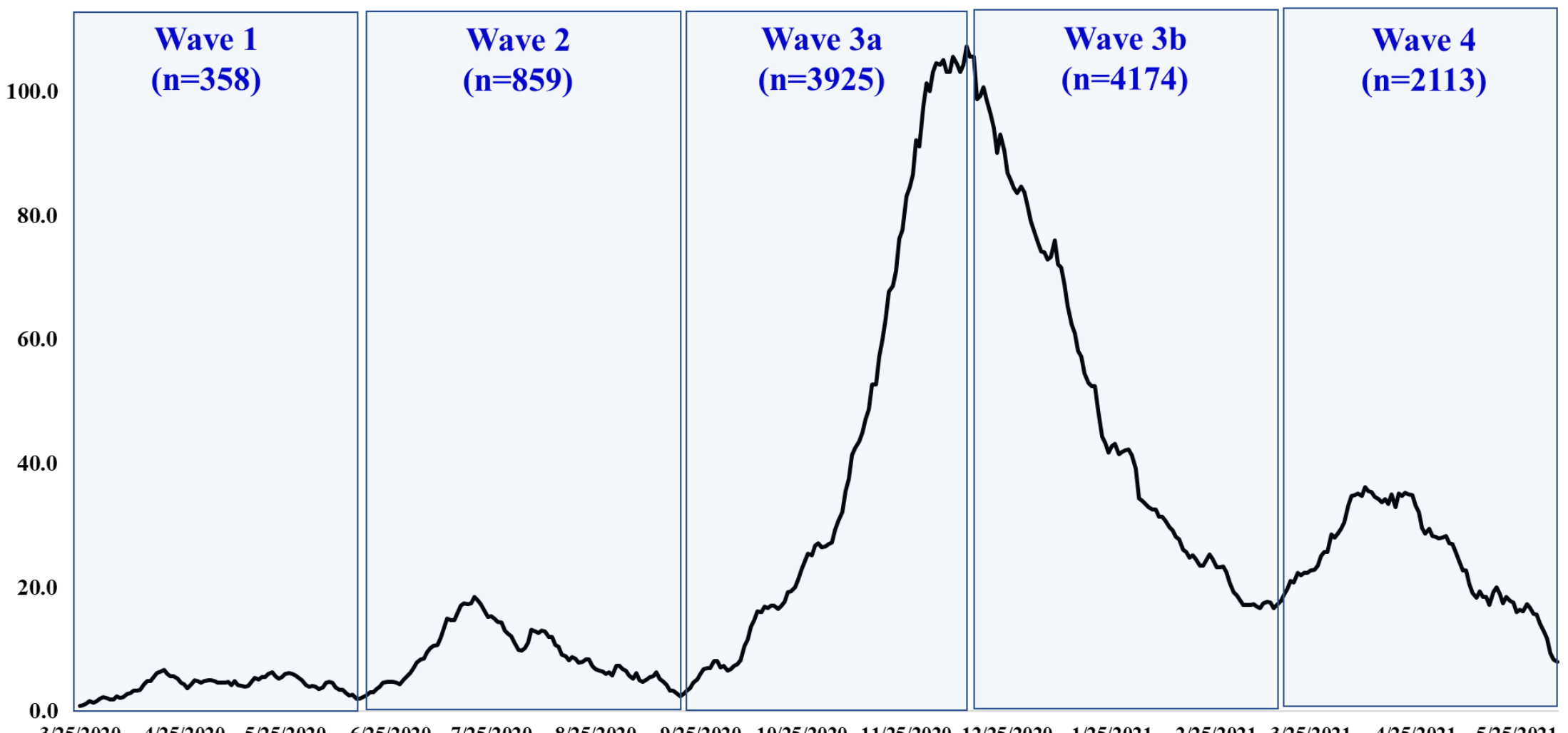




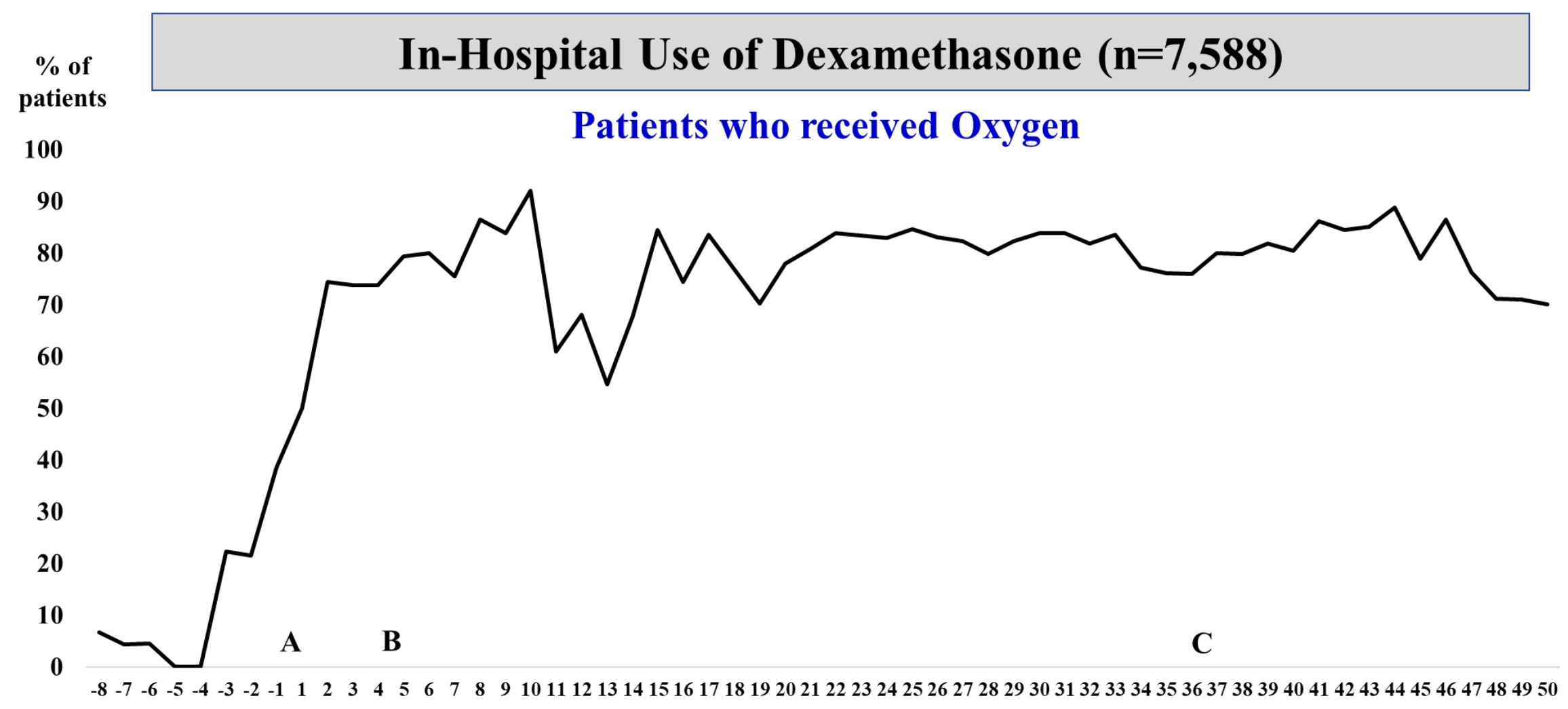
A. $(6 / 22 / 2020)$
Preliminary results of RECOVERY trial published in Med Rxiv ${ }^{9}$
B. $(7 / 17 / 2020)$
Results of RECOVERY trial published online in NEJM ${ }^{10}$
C. $(2 / 25 / 2021)$
RECOVERY trial results published in print in NEJM ${ }^{10}$

Figure 2 


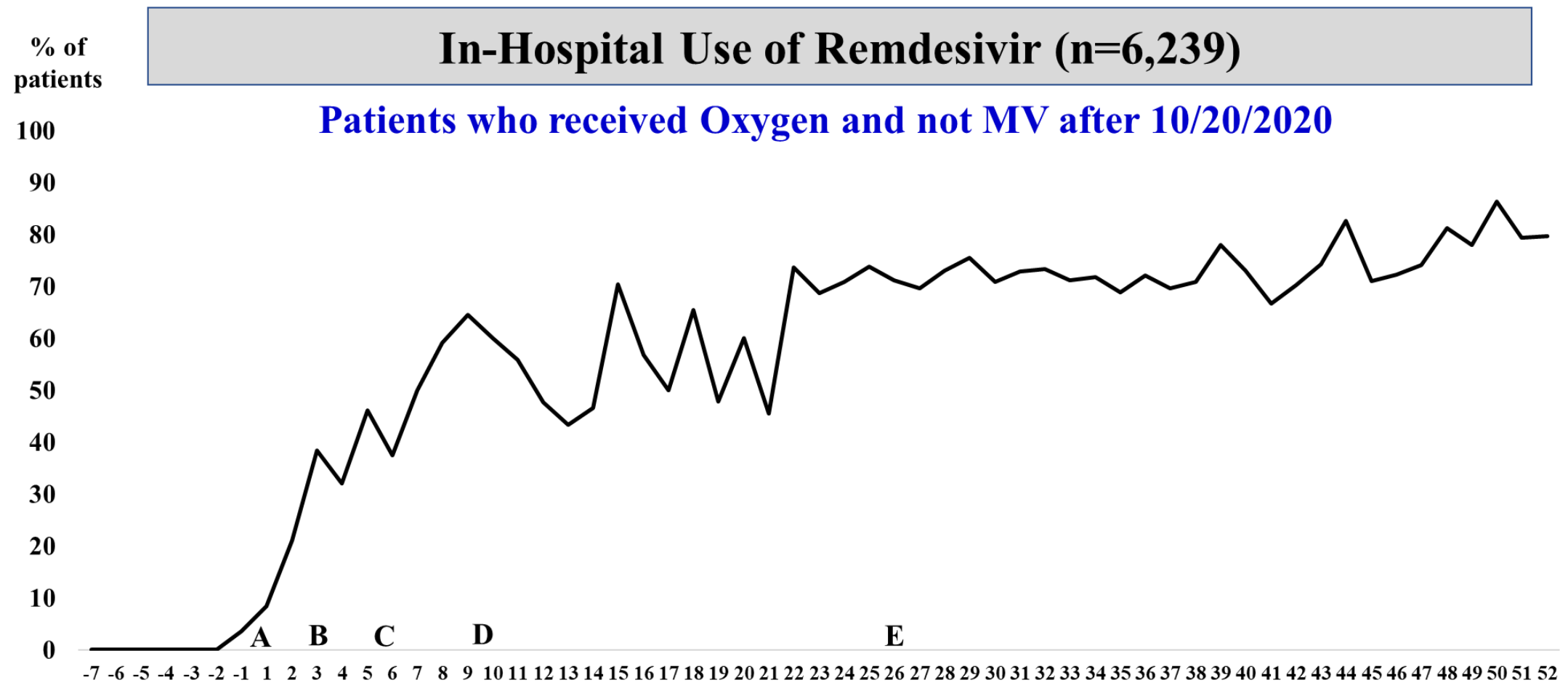
A. $(5 / 1 / 2020)$
FDA issues EUA for Remdesivir for people hospitalized with severe COVID-19 11
B. $(5 / 15 / 2020)$
UPMC receives first shipment of Remdesivir and begins lottery system (5/18) due to limited supply
C. $(6 / 1 / 2020)$
Gilead announces results from Phase 3 trial of Remdesivir ${ }^{12}$
D. $(6 / 29 / 2020)$
U.S. government announces purchase of $>90 \%$ of Remdesivir that Gilead will produce (summer, 2020) ${ }^{13}$
E. $(10 / 22 / 2020)$
FDA approves Remdesivir as the first COVID-19 drug ${ }^{14}$
Figure 3 


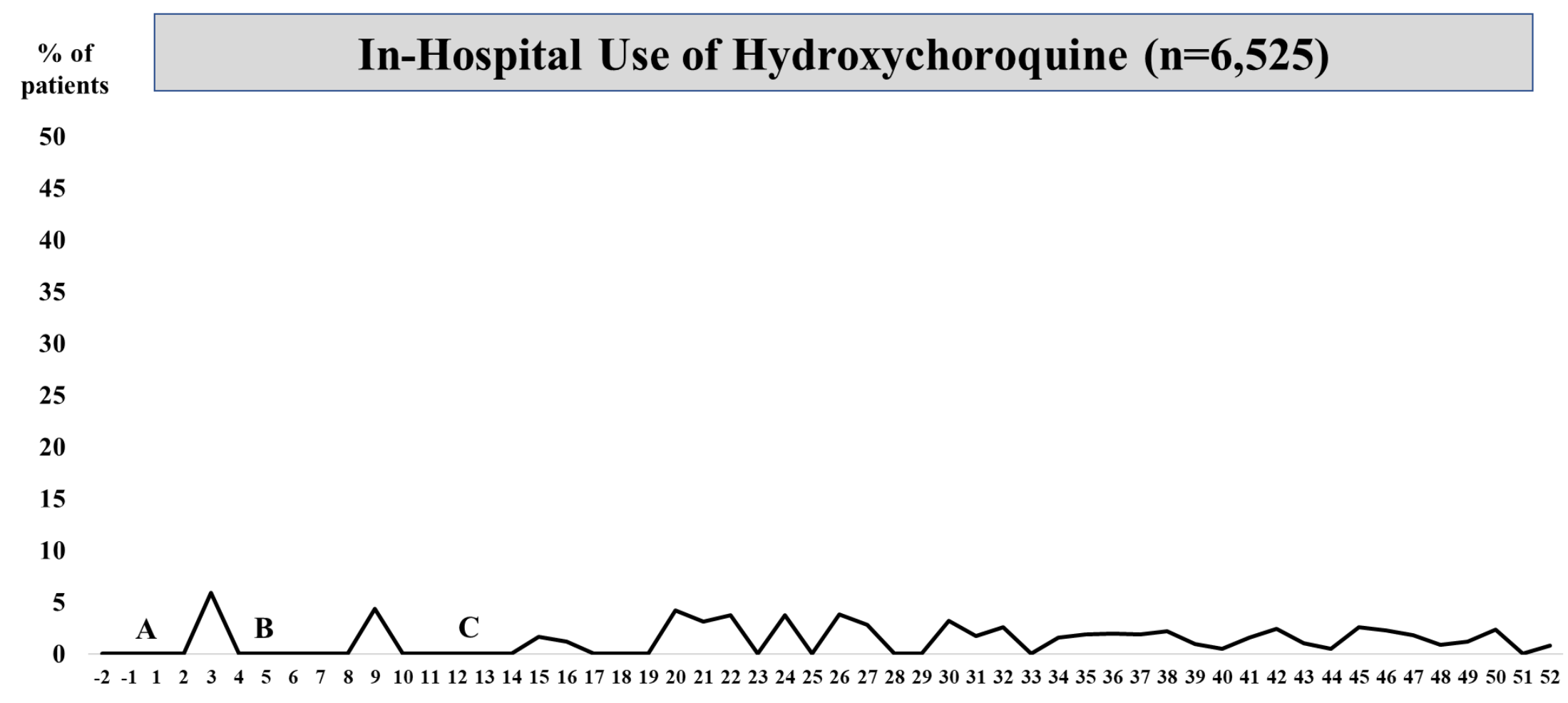
A. (3/28/2020) FDA grants Emergency Use Authorization (EUA) ${ }^{15}$
B. $(4 / 24 / 2020)$
FDA issues warning that cardiac arrhythmias have been associated with hydroxychloroquine and chloroquine, recommending against their use outside of clinical trials ${ }^{17}$
C. $(6 / 15 / 2020)$
FDA revokes its EUA for chloroquine and hydroxychloroquine ${ }^{18}$
Figure 4 


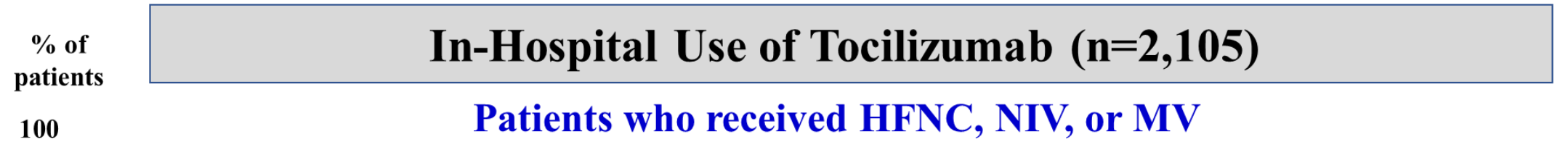

90

80

70

60

50

40

30

20

10

0

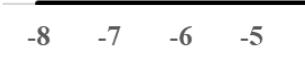
A. $(1 / 9 / 2021)$
REMAP-CAP trial results reported in Med Rxiv show improved outcome and survival with use of tocilizumab in critically ill patients with COVID-19 receiving organ support ${ }^{19}$
B. $(2 / 11 / 2021)$
RECOVERY Group trial results reported in Med Rxiv show improved survival and other clinical outcomes in hospitalized COVID-19 patients with hypoxia and systemic inflammation ${ }^{20}$
C. $(2 / 25 / 2021)$ REMAP-CAP trial results (listed above in "A") published in New England Journal of Medicine ${ }^{21}$ 
Supplemental Table 1. Listing of UPMC Hospitals by Type, Bed Capacity, and Volume

\begin{tabular}{|c|c|c|c|}
\hline Hospital Type & Hospital Name & $\begin{array}{c}\text { Number of } \\
\text { Licensed Beds }\end{array}$ & $\begin{array}{c}\text { Number of Patients } \\
\text { in Analysis }\end{array}$ \\
\hline Large Academic & Children's & 315 & 230 \\
\hline Large Academic & Magee & 335 & 379 \\
\hline Large Academic & Mercy & 404 & 857 \\
\hline Large Academic & Presbyterian & 900 & 959 \\
\hline Large Academic & Shadyside & 520 & 936 \\
\hline Large Community & Altoona & 380 & 1444 \\
\hline Large Community & East & 155 & 751 \\
\hline Large Community & Hamot & 412 & 849 \\
\hline Large Community & McKeesport & 216 & 442 \\
\hline Large Community & Passavant & 394 & 970 \\
\hline Large Community & St. Margaret & 249 & 719 \\
\hline Large Community & Williamsport & 224 & 866 \\
\hline Large Community & Western Psych & 263 & 77 \\
\hline Small Community & Bedford & 49 & 196 \\
\hline Small Community & Chautauqua & 277 & 246 \\
\hline Small Community & Cranberry & 35 & 89 \\
\hline Small Community & Horizon & 106 & 262 \\
\hline Small Community & Jameson & 236 & 408 \\
\hline Small Community & Lock Haven & 25 & 118 \\
\hline Small Community & Muncy & 156 & 74 \\
\hline Small Community & Northwest & 126 & 359 \\
\hline Small Community & Soldiers \& Sailors & 67 & 198 \\
\hline
\end{tabular}


Supplemental Table S2. Checklist: The REporting of studies Conducted using Observational Routinely-Collected health Data (RECORD) statement.

\begin{tabular}{|c|c|c|c|c|c|}
\hline & $\begin{array}{l}\text { Item } \\
\text { No. }\end{array}$ & STROBE items & $\begin{array}{l}\text { Location in } \\
\text { manuscript where } \\
\text { items are reported }\end{array}$ & RECORD items & $\begin{array}{l}\text { Location in } \\
\text { manuscript where } \\
\text { items are } \\
\text { reported } \\
\end{array}$ \\
\hline \multicolumn{6}{|c|}{ Title and abstract } \\
\hline & 1 & $\begin{array}{l}\text { (a) Indicate the study's design with } \\
\text { a commonly used term in the title } \\
\text { or the abstract (b) Provide in the } \\
\text { abstract an informative and } \\
\text { balanced summary of what was } \\
\text { done and what was found }\end{array}$ & Abstract, Pages 3-4 & $\begin{array}{l}\text { RECORD 1.1: The type of data used } \\
\text { should be specified in the title or abstract. } \\
\text { When possible, the name of the databases } \\
\text { used should be included. } \\
\text { RECORD 1.2: If applicable, the } \\
\text { geographic region and timeframe within } \\
\text { which the study took place should be } \\
\text { reported in the title or abstract. } \\
\text { RECORD 1.3: If linkage between } \\
\text { databases was conducted for the study, } \\
\text { this should be clearly stated in the title or } \\
\text { abstract. }\end{array}$ & $\begin{array}{l}\text { Abstract, Page } 3 \\
\text { Abstract, Page } 3 \\
\text { Abstract, Page } 3\end{array}$ \\
\hline \multicolumn{6}{|l|}{ Introduction } \\
\hline $\begin{array}{l}\text { Background } \\
\text { rationale }\end{array}$ & 2 & $\begin{array}{l}\text { Explain the scientific background } \\
\text { and rationale for the investigation } \\
\text { being reported }\end{array}$ & $\begin{array}{l}\text { Introduction, Pages 5- } \\
6\end{array}$ & & \\
\hline Objectives & 3 & $\begin{array}{l}\text { State specific objectives, including } \\
\text { any prespecified hypotheses }\end{array}$ & Introduction, Page 6 & & \\
\hline \multicolumn{6}{|l|}{ Methods } \\
\hline Study Design & 4 & $\begin{array}{l}\text { Present key elements of study } \\
\text { design early in the paper }\end{array}$ & Methods, Pages 6-9 & & \\
\hline Setting & 5 & $\begin{array}{l}\text { Describe the setting, locations, and } \\
\text { relevant dates, including periods of } \\
\text { recruitment, exposure, follow-up, } \\
\text { and data collection }\end{array}$ & Methods, Pages 6-9 & & \\
\hline Participants & 6 & $\begin{array}{l}\text { (a) Cohort study - Give the } \\
\text { eligibility criteria, and the sources } \\
\text { and methods of selection of } \\
\text { participants. Describe methods of } \\
\text { follow-up }\end{array}$ & Methods, Pages 8-9 & $\begin{array}{l}\text { RECORD 6.1: The methods of study } \\
\text { population selection (such as codes or } \\
\text { algorithms used to identify subjects) } \\
\text { should be listed in detail. If this is not } \\
\text { possible, an explanation should be } \\
\text { provided. }\end{array}$ & $\begin{array}{l}\text { Methods, Pages 8- } \\
9\end{array}$ \\
\hline
\end{tabular}




\begin{tabular}{|c|c|c|c|c|c|}
\hline & & $\begin{array}{l}\text { Case-control study - Give the } \\
\text { eligibility criteria, and the sources } \\
\text { and methods of case ascertainment } \\
\text { and control selection. Give the } \\
\text { rationale for the choice of cases } \\
\text { and controls } \\
\text { Cross-sectional study - Give the } \\
\text { eligibility criteria, and the sources } \\
\text { and methods of selection of } \\
\text { participants } \\
\text { (b) Cohort study - For matched } \\
\text { studies, give matching criteria and } \\
\text { number of exposed and unexposed } \\
\text { Case-control study - For matched } \\
\text { studies, give matching criteria and } \\
\text { the number of controls per case }\end{array}$ & N/A & $\begin{array}{l}\text { RECORD 6.2: Any validation studies of } \\
\text { the codes or algorithms used to select the } \\
\text { population should be referenced. If } \\
\text { validation was conducted for this study } \\
\text { and not published elsewhere, detailed } \\
\text { methods and results should be provided. } \\
\text { RECORD 6.3: If the study involved } \\
\text { linkage of databases, consider use of a } \\
\text { flow diagram or other graphical display to } \\
\text { demonstrate the data linkage process, } \\
\text { including the number of individuals with } \\
\text { linked data at each stage. }\end{array}$ & $\begin{array}{l}\text { Methods, Pages 6- } \\
7 \text {, described in text }\end{array}$ \\
\hline Variables & 7 & $\begin{array}{l}\text { Clearly define all outcomes, } \\
\text { exposures, predictors, potential } \\
\text { confounders, and effect modifiers. } \\
\text { Give diagnostic criteria, if } \\
\text { applicable. }\end{array}$ & Methods, Pages 8-9 & $\begin{array}{l}\text { RECORD 7.1: A complete list of codes } \\
\text { and algorithms used to classify exposures, } \\
\text { outcomes, confounders, and effect } \\
\text { modifiers should be provided. If these } \\
\text { cannot be reported, an explanation should } \\
\text { be provided. }\end{array}$ & $\begin{array}{l}\text { The coding of all } \\
\text { variables across the } \\
\text { different EMRs is } \\
\text { too voluminous to } \\
\text { individually report. }\end{array}$ \\
\hline $\begin{array}{l}\text { Data sources/ } \\
\text { measurement }\end{array}$ & 8 & $\begin{array}{l}\text { For each variable of interest, give } \\
\text { sources of data and details of } \\
\text { methods of assessment } \\
\text { (measurement). } \\
\text { Describe comparability of } \\
\text { assessment methods if there is } \\
\text { more than one group }\end{array}$ & Methods, Pages 8-9 & & \\
\hline Bias & 9 & $\begin{array}{l}\text { Describe any efforts to address } \\
\text { potential sources of bias }\end{array}$ & Methods, Page 9 & & \\
\hline Study size & 10 & $\begin{array}{l}\text { Explain how the study size was } \\
\text { arrived at }\end{array}$ & Methods, Pages 7-8 & & \\
\hline $\begin{array}{l}\text { Quantitative } \\
\text { variables }\end{array}$ & 11 & $\begin{array}{l}\text { Explain how quantitative variables } \\
\text { were handled in the analyses. If } \\
\text { applicable, describe which } \\
\text { groupings were chosen, and why }\end{array}$ & Methods, Pages 8-9 & & \\
\hline
\end{tabular}

Page $\mathbf{3 5}$ of $\mathbf{4 5}$ 


\begin{tabular}{|c|c|c|c|c|c|}
\hline Statistical methods & 12 & $\begin{array}{l}\text { (a) Describe all statistical methods, } \\
\text { including those used to control for } \\
\text { confounding } \\
\text { (b) Describe any methods used to } \\
\text { examine subgroups and } \\
\text { interactions } \\
\text { (c) Explain how missing data were } \\
\text { addressed } \\
\text { (d) Cohort study - If applicable, } \\
\text { explain how loss to follow-up was } \\
\text { addressed } \\
\text { Case-control study - If applicable, } \\
\text { explain how matching of cases and } \\
\text { controls was addressed } \\
\text { Cross-sectional study - If } \\
\text { applicable, describe analytical } \\
\text { methods taking account of } \\
\text { sampling strategy } \\
\text { (e) Describe any sensitivity } \\
\text { analyses }\end{array}$ & $\begin{array}{l}\text { Methods, Page } 9 \\
\text { Methods, Page } 9 \\
\text { Methods, Page 9-10 }\end{array}$ & & \\
\hline $\begin{array}{l}\text { Data access and } \\
\text { cleaning methods }\end{array}$ & & .. & & $\begin{array}{l}\text { RECORD 12.1: Authors should describe } \\
\text { the extent to which the investigators had } \\
\text { access to the database population used to } \\
\text { create the study population. } \\
\text { RECORD 12.2: Authors should provide } \\
\text { information on the data cleaning methods } \\
\text { used in the study. }\end{array}$ & $\begin{array}{l}\text { Methods, Pages 7- } \\
9 \\
\text { Methods, Pages 7- } \\
9\end{array}$ \\
\hline Linkage & &.. & & $\begin{array}{l}\text { RECORD 12.3: State whether the study } \\
\text { included person-level, institutional-level, } \\
\text { or other data linkage across two or more } \\
\text { databases. The methods of linkage and } \\
\text { methods of linkage quality evaluation } \\
\text { should be provided. }\end{array}$ & $\begin{array}{l}\text { Methods, Pages 8- } \\
9\end{array}$ \\
\hline \multicolumn{6}{|l|}{ Results } \\
\hline Participants & 13 & $\begin{array}{l}\text { (a) Report the numbers of } \\
\text { individuals at each stage of the } \\
\text { study (e.g., numbers potentially } \\
\text { eligible, examined for eligibility, } \\
\text { confirmed eligible, included in the }\end{array}$ & Methods, Pages 8-9 & $\begin{array}{l}\text { RECORD 13.1: Describe in detail the } \\
\text { selection of the persons included in the } \\
\text { study (i.e., study population selection) } \\
\text { including filtering based on data quality, } \\
\text { data availability and linkage. The }\end{array}$ & $\begin{array}{l}\text { Methods, Pages 8- } \\
9 \\
\text { Supplemental } \\
\text { Figure S1 }\end{array}$ \\
\hline
\end{tabular}




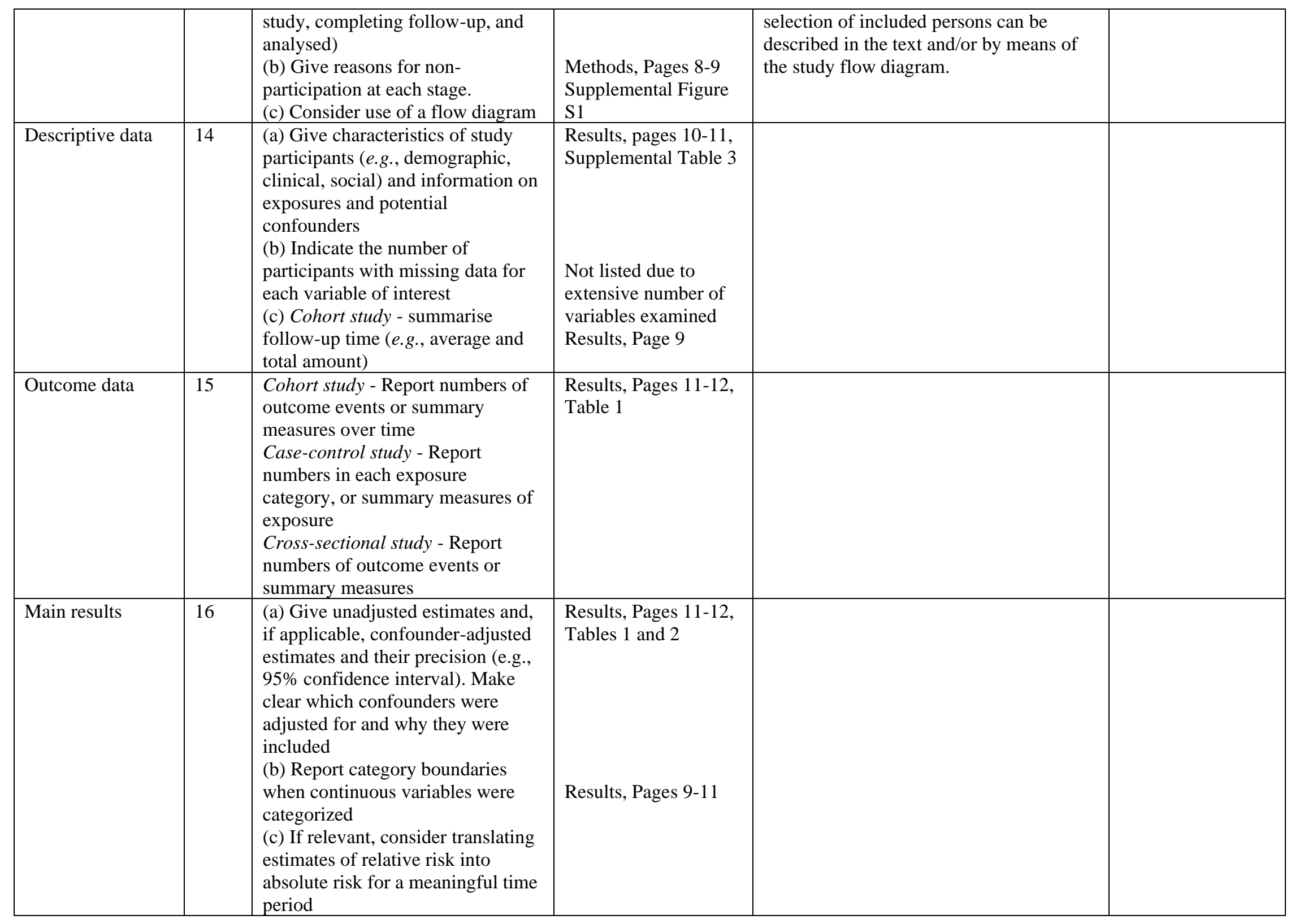




\begin{tabular}{|c|c|c|c|c|c|}
\hline Other analyses & 17 & $\begin{array}{l}\text { Report other analyses done-e.g., } \\
\text { analyses of subgroups and } \\
\text { interactions, and sensitivity } \\
\text { analyses }\end{array}$ & Results, Page 10 & & \\
\hline \multicolumn{6}{|l|}{ Discussion } \\
\hline Key results & 18 & $\begin{array}{l}\text { Summarise key results with } \\
\text { reference to study objectives }\end{array}$ & $\begin{array}{l}\text { Discussion, page 12- } \\
13\end{array}$ & & \\
\hline Limitations & 19 & $\begin{array}{l}\text { Discuss limitations of the study, } \\
\text { taking into account sources of } \\
\text { potential bias or imprecision. } \\
\text { Discuss both direction and } \\
\text { magnitude of any potential bias }\end{array}$ & Discussion, Page 14 & $\begin{array}{l}\text { RECORD 19.1: Discuss the implications } \\
\text { of using data that were not created or } \\
\text { collected to answer the specific research } \\
\text { question(s). Include discussion of } \\
\text { misclassification bias, unmeasured } \\
\text { confounding, missing data, and changing } \\
\text { eligibility over time, as they pertain to the } \\
\text { study being reported. }\end{array}$ & $\begin{array}{l}\text { Discussion, Page } \\
14\end{array}$ \\
\hline Interpretation & 20 & $\begin{array}{l}\text { Give a cautious overall } \\
\text { interpretation of results considering } \\
\text { objectives, limitations, multiplicity } \\
\text { of analyses, results from similar } \\
\text { studies, and other relevant evidence }\end{array}$ & $\begin{array}{l}\text { Discussion, Pages 12- } \\
14\end{array}$ & & \\
\hline Generalisability & 21 & $\begin{array}{l}\text { Discuss the generalisability } \\
\text { (external validity) of the study } \\
\text { results }\end{array}$ & Discussion, Page 14 & & \\
\hline \multicolumn{6}{|l|}{ Other Information } \\
\hline Funding & 22 & $\begin{array}{l}\text { Give the source of funding and the } \\
\text { role of the funders for the present } \\
\text { study and, if applicable, for the } \\
\text { original study on which the present } \\
\text { article is based }\end{array}$ & Title Page, Page 1 & & \\
\hline $\begin{array}{l}\text { Accessibility of } \\
\text { protocol, raw data, } \\
\text { and programming } \\
\text { code }\end{array}$ & &.. & & $\begin{array}{l}\text { RECORD 22.1: Authors should provide } \\
\text { information on how to access any } \\
\text { supplemental information such as the } \\
\text { study protocol, raw data, or programming } \\
\text { code. }\end{array}$ & $\begin{array}{l}\text { Supplemental } \\
\text { information } \\
\text { including raw data } \\
\text { are not permissible } \\
\text { from this analysis. }\end{array}$ \\
\hline
\end{tabular}

*Reference: Benchimol EI, Smeeth L, Guttmann A, Harron K, Moher D, Petersen I, Sørensen HT, von Elm E, Langan SM, the RECORD Working Committee.

The REporting of studies Conducted using Observational Routinely-collected health Data (RECORD) Statement. PLoS Medicine 2015; in press.

$*$ Checklist is protected under Creative Commons Attribution ( $\underline{\mathrm{CC} B Y})$ license. 
Supplemental Table 3. Presenting Characteristics of Hospitalized Patients by Admission Wave

\begin{tabular}{|c|c|c|c|c|c|c|}
\hline Characteristic & Wave 1 & Wave 2 & Wave 3a & Wave 3b & Wave 4 & $\begin{array}{c}\text { P- } \\
\text { value }\end{array}$ \\
\hline & $(\mathrm{N}=358)$ & $(\mathrm{N}=859)$ & $(\mathrm{N}=3925)$ & $(\mathrm{N}=4174)$ & $(\mathrm{N}=2113)$ & \\
\hline Age in years, mean, median & $66.3,69$ & $64.3,67$ & $68.7,72$ & $67.7,70$ & $59.5,62$ & $<.001$ \\
\hline Age 50 years or younger, (No.), $\%$ & (53) 14.8 & (179) 20.8 & (495) 12.6 & (579) 13.9 & $(565) 26.7$ & $<.001$ \\
\hline Female gender, (No.), \% & (184) 51.4 & (422) 49.1 & (1887) 48.1 & 48.0 & (1073) 50.8 & .19 \\
\hline \multicolumn{7}{|l|}{ Race, (No.), \% } \\
\hline White & $(220) 63.6$ & $(575) 69.2$ & $(3284) 86.0$ & $(3590) 88.2$ & (1581) 77.2 & $<.001$ \\
\hline Black & (122) 35.3 & (233) 28.0 & (467) 12.2 & (433) 10.6 & (453) 22.1 & \\
\hline Other & (4) 1.2 & (23) 2.8 & (67) 1.8 & (49) 1.2 & (15) 0.7 & \\
\hline \multicolumn{7}{|l|}{ Smoking history, (No.), \% } \\
\hline Current & (18) 9.6 & (41) 7.4 & (168) 6.3 & (187) 6.7 & (149) 11.3 & $<.001$ \\
\hline Former & (74) 39.6 & (246) 44.2 & (1247) 46.8 & (1324) 47.4 & (538) 40.8 & \\
\hline Never & (95) 50.8 & (269) 48.4 & (1250) 46.9 & 4 (1283) 45.9 & $4632) 47.9$ & \\
\hline Current alcohol use, (No.), $\%$ & (49) 27.2 & (185) 34.3 & (900) 34.6 & (920) 33.7 & (422) 33.5 & .36 \\
\hline Current illicit drug use, (No.), $\%$ & (6) 3.4 & (21) 4.0 & (82) 3.2 & (83) 3.1 & (49) 4.0 & .60 \\
\hline \multicolumn{7}{|l|}{ Medical History } \\
\hline History of diabetes, (No.), \% & (71) 36.2 & (210) 37.3 & (998) 37.1 & 37.2 & (429) 32.0 & .01 \\
\hline History of hypertension, (No.), \% & $(115) 58.7$ & $(345) 61.3$ & $(1788) 66.5$ & (1852) 65.5 & $(830) 61.9$ & .004 \\
\hline History of portal hypertension, (No.), \% & (33) 16.8 & (72) 12.8 & (334) 12.4 & (332) 11.7 & (154) 11.5 & .24 \\
\hline History of hyperlipidemia, (No.), $\%$ & (103) 52.6 & (311) 55.2 & (1605) 59.7 & $(1667) 58.9$ & (710) 53.0 & $<.001$ \\
\hline History of morbid obesity, (No.), $\%$ & (49) 25.0 & (141) 25.0 & (609) 22.7 & (660) 23.3 & (351) 26.2 & .13 \\
\hline History of obstructive sleep apnea, (No.), \% & (40) 20.4 & (126) 22.4 & (594) 22.1 & (636) 22.5 & 20.3 & .56 \\
\hline History of atrial fibrillation, (No.), $\%$ & (29) 14.8 & (75) 13.3 & (426) 15.8 & (471) 16.6 & (160) 11.9 & .001 \\
\hline History of coronary artery disease, (No.), \% & (45) 23.0 & (117) 20.8 & (697) 25.9 & (739) 26.1 & (274) 20.4 & $<.001$ \\
\hline History of vascular disease, (No.), $\%$ & (13) 6.6 & (46) 8.2 & (243) 9.0 & (255) 9.0 & $(105) 7.8$ & .51 \\
\hline History of major bleed, (No.), $\%$ & (50) 25.5 & (126) 22.4 & (657) 24.4 & $(726) 25.7$ & (298) 22.2 & 12 \\
\hline History of congestive heart failure, (No.), $\%$ & (37) 18.9 & (91) 16.2 & (529) 19.7 & (601) 21.2 & (255) 19.0 & .06 \\
\hline History of asthma, (No.), $\%$ & (60) 30.6 & (203) 36.1 & (950) 35.3 & (1032) 36.5 & (500) 37.2 & .38 \\
\hline
\end{tabular}




\begin{tabular}{|c|c|c|c|c|c|c|}
\hline History of COPD, (No.), \% & (40) 20.4 & (132) 23.4 & $(658) 24.5$ & (738) 26.1 & (350) 26.1 & .21 \\
\hline History of pulmonary embolism, (No.), \% & (14) 7.1 & (16) 2.8 & (119) 4.4 & (140) 4.9 & (53) 3.9 & .06 \\
\hline History of chronic kidney disease, (No.), $\%$ & (43) 21.9 & (88) 15.6 & (497) 18.5 & (594) 21.0 & (208) 15.5 & $<.001$ \\
\hline History of cancer, (No.), \% & (40) 20.4 & (94) 16.7 & (548) 20.4 & $(588) 20.8$ & (200) 14.9 & $<.001$ \\
\hline History of hypothyroidism, (No.), $\%$ & (38) 19.4 & (96) 17.1 & $(567) 21.1$ & $(607) 21.5$ & (234) 17.4 & .008 \\
\hline History of low back pain, (No.), $\%$ & (63) 32.1 & (202) 35.9 & (958) 35.6 & 35.3 & (439) 32.7 & .34 \\
\hline History of ascites, (No.), \% & (50) 25.5 & (115) 20.4 & (719) 26.7 & $(723) 25.6$ & (277) 20.7 & $<.001$ \\
\hline History of anxiety, (No.), \% & (35) 17.9 & (96) 17.1 & $(544) 20.2$ & (557) 19.7 & (304) 22.7 & .05 \\
\hline History of depression, (No.), \% & (35) 17.9 & (107) 19.0 & (499) 18.6 & (507) 17.9 & (264) 19.7 & .73 \\
\hline CCI total score, mean (median) & $1.8,1$ & $1.5,1$ & $1.7,1$ & $1.7,1$ & $1.5,1$ & $<.001$ \\
\hline $\begin{array}{l}\text { Estimated risk (\%) of mortality within } 90 \text { days after } \\
\text { hospitalization, mean (median) }\end{array}$ & $29.0,22$ & $22.8,16$ & $27.8,24$ & $26.9,22$ & $20.9,14$ & $<.001$ \\
\hline \multicolumn{7}{|l|}{ Medications } \\
\hline ACE, (No.), \% & (40) 20.4 & (128) 22.7 & $(661) 24.6$ & (670) 23.7 & (305) 22.7 & .51 \\
\hline ARB, (No.), \% & (22) 11.2 & (88) 15.6 & (422) 15.7 & (430) 15.2 & (183) 13.6 & .25 \\
\hline Beta-blocker, (No.), \% & (91) 46.4 & (220) 39.1 & (1213) 45.1 & (1279) 45.2 & (506) 37.7 & $<.001$ \\
\hline Calcium channel blocker, (No.), $\%$ & (53) 27.0 & (140) 24.9 & (786) 29.2 & $(798) 28.2$ & (363) 27.1 & .24 \\
\hline Diuretic, (No.), \% & (70) 35.7 & (190) 33.7 & (1022) 38.0 & 37.5 & (430) 32.1 & .002 \\
\hline DOACS, (No.), \% & (33) 16.8 & (66) 11.7 & (399) 14.8 & (411) 14.5 & (147) 11.0 & .003 \\
\hline Warfarin, (No.), \% & (13) 6.6 & (29) 5.2 & (177) 6.6 & $(184) 6.5$ & (49) 3.7 & .002 \\
\hline Anti-platelet, (No.), $\%$ & $(68) 34.7$ & (186) 33.0 & (980) 36.5 & (1007) 35.6 & (375) 28.0 & $<.001$ \\
\hline Insulin, (No.), \% & (43) 21.9 & (115) 20.4 & (504) 18.7 & (499) 17.6 & (205) 15.3 & .02 \\
\hline Metformin, (No.), \% & (33) 16.8 & (113) 20.1 & (544) 20.2 & $(525) 18.6$ & (224) 16.7 & .07 \\
\hline Statin, (No.), \% & (109) 55.6 & $(295) 52.4$ & (1519) 56.5 & (1601) 56.6 & (582) 43.4 & $<.001$ \\
\hline Short acting bronchodilator, (No.), \% & (52) 26.5 & (138) 24.5 & $(689) 25.6$ & (792) 28.0 & (350) 26.1 & .24 \\
\hline Anti-depressant, (No.), \% & (89) 45.4 & (204) 36.2 & (1034) 38.5 & 39.0 & (459) 34.2 & .005 \\
\hline Corticosteroids, (No.), $\%$ & (67) 34.2 & (216) 38.4 & (1097) 40.8 & (1125) 39.8 & (528) 39.4 & .37 \\
\hline Prednisone, (No.), $\%$ & (21) 10.7 & (74) 13.1 & (353) 13.1 & (367) 13.0 & (175) 13.1 & .92 \\
\hline Immunomodulators, (No.), \% & (4) 2.0 & (7) 1.2 & (62) 2.3 & (71) 2.5 & (23) 1.7 & .26 \\
\hline Muscle relaxant, (No.), \% & (19) 9.7 & (64) 11.4 & (316) 11.8 & $(300) 10.6$ & (168) 12.5 & .36 \\
\hline
\end{tabular}




\begin{tabular}{|c|c|c|c|c|c|c|}
\hline NSAIDS, (No.), $\%$ & (56) 28.6 & (163) 29.0 & (720) 26.8 & (758) 26.8 & $(382) 28.5$ & .63 \\
\hline Opioids, (No.), \% & (42) 21.4 & (147) 26.1 & (709) 26.4 & (757) 26.8 & (314) 23.4 & .10 \\
\hline \multicolumn{7}{|l|}{ Laboratory values } \\
\hline White blood cells, mean, median & $7.6,6$ & $7.3,6$ & $8.1,7$ & $8.6,7$ & $7.6,7$ & $<.001$ \\
\hline Lymphocytes, mean, median & $15.5,13$ & $16.4,14$ & $14.7,13$ & $13.8,12$ & $15.8,13$ & $<.001$ \\
\hline Neutrophils, mean, median & $74.6,76$ & $73.1,75$ & $75.1,78$ & $76.2,78$ & $74.3,77$ & $<.001$ \\
\hline Hemoglobin, mean, median & $12.4,13$ & $12.7,13$ & $12.7,13$ & $12.7,13$ & $13.0,13$ & $<.001$ \\
\hline Platelets, mean, median & $218.9,195$ & $214.6,198$ & $210.0,195$ & $221.4,206$ & $216.2,200$ & $<.001$ \\
\hline AST, mean, median & $56.1,38$ & $45.8,31$ & $55.6,34$ & $57.2,34$ & $51.5,35$ & $<.001$ \\
\hline ALT, mean, median & $42.4,28$ & $37.2,27$ & $42.4,27$ & $45.1,28$ & $42.4,30$ & $<.001$ \\
\hline Creatinine, mean, median & $1.6,1$ & $1.4,1$ & $1.5,1$ & $1.6,1$ & $1.5,1$ & $<.001$ \\
\hline \multicolumn{7}{|c|}{ Neutrophil to lymphocyte ratio, (No.), \% } \\
\hline Less than or equal to 3.0 & (56) 21.5 & $(150) 22.5$ & (633) 19.3 & $(568) 16.7$ & (360) 21.5 & $<.001$ \\
\hline 3.0 to 6.0 & (80) 30.7 & $(228) 34.2$ & (977) 29.7 & (950) 28.0 & (521) 31.1 & \\
\hline More than 6.0 & (125) 47.9 & (288) 43.2 & (1676) 51.0 & (1876) 55.3 & (795) 47.4 & \\
\hline \multicolumn{7}{|c|}{ Systemic Inflammatory Index, (No.), \% } \\
\hline SII $<=300$ & (17) 6.6 & (64) 9.6 & $(251) 7.7$ & $(213) 6.3$ & $(133) 8.0$ & $<0.001$ \\
\hline SII $>300$ to $<=600$ & (48) 18.5 & (133) 20.0 & (558) 17.0 & (457) 13.5 & (293) 17.5 & \\
\hline SII $>600$ to $<=900$ & (40) 15.4 & (103) 15.5 & $(477) 14.5$ & (456) 13.4 & $(288) 17.2$ & \\
\hline SII $>900$ & (154) 59.5 & (366) 55.0 & (1997) 60.8 & 66.8 & 57.3 & \\
\hline
\end{tabular}

Wave 1: - March 19 - June 16, 2020; Wave 2: June 17 - September 19, 2020; Wave 3a: September 20 December 13, 2020; Wave 3b: December 14, 2020 - March 10, 2021; Wave 4: March 11 - June 6, 2021. 


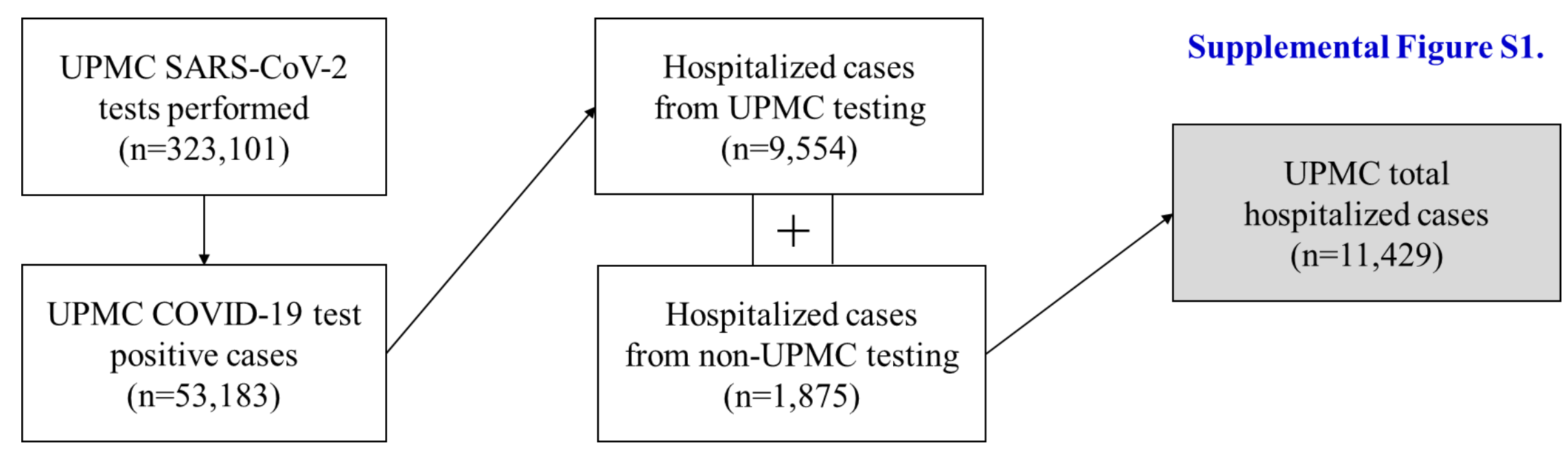




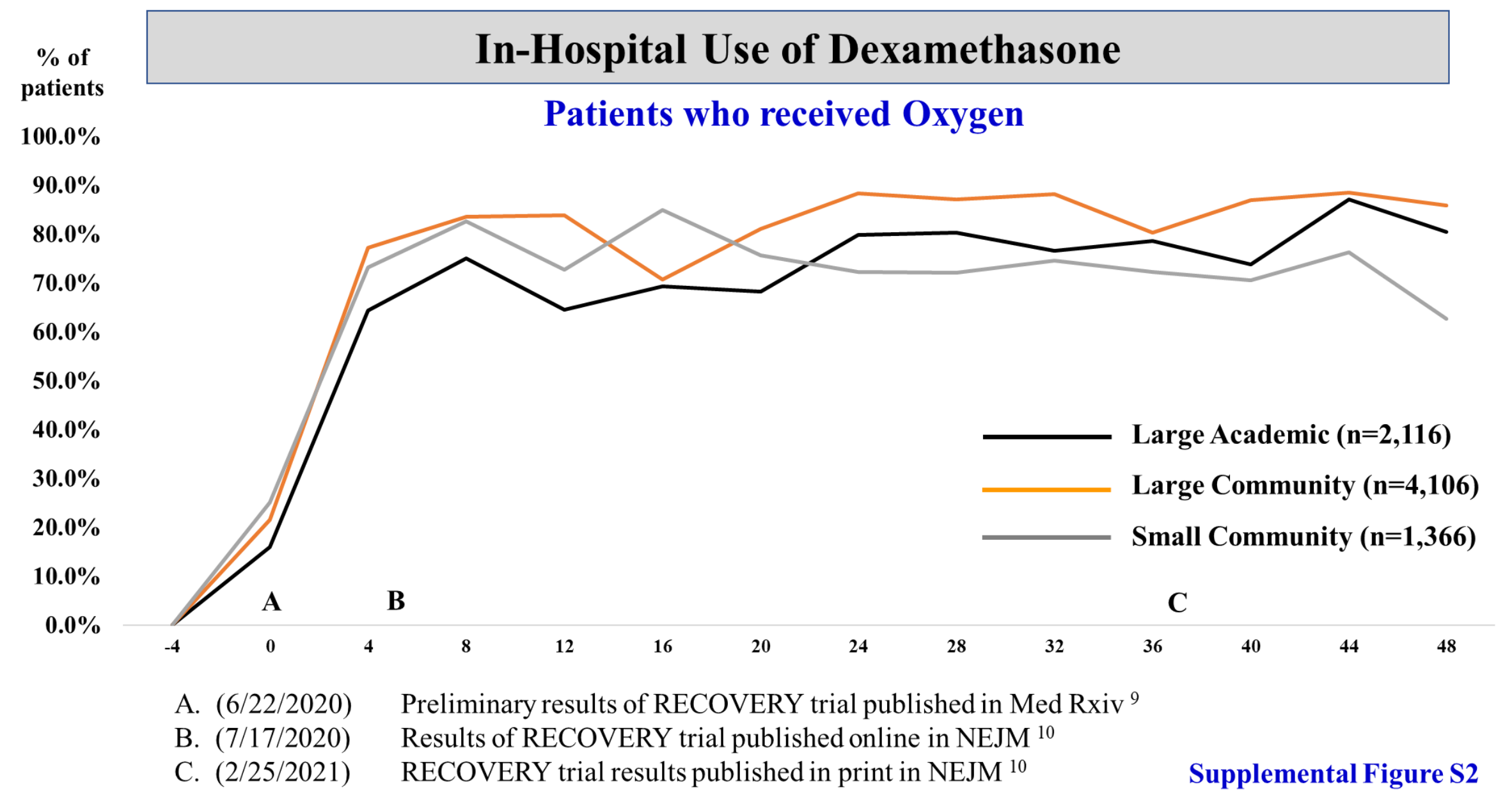




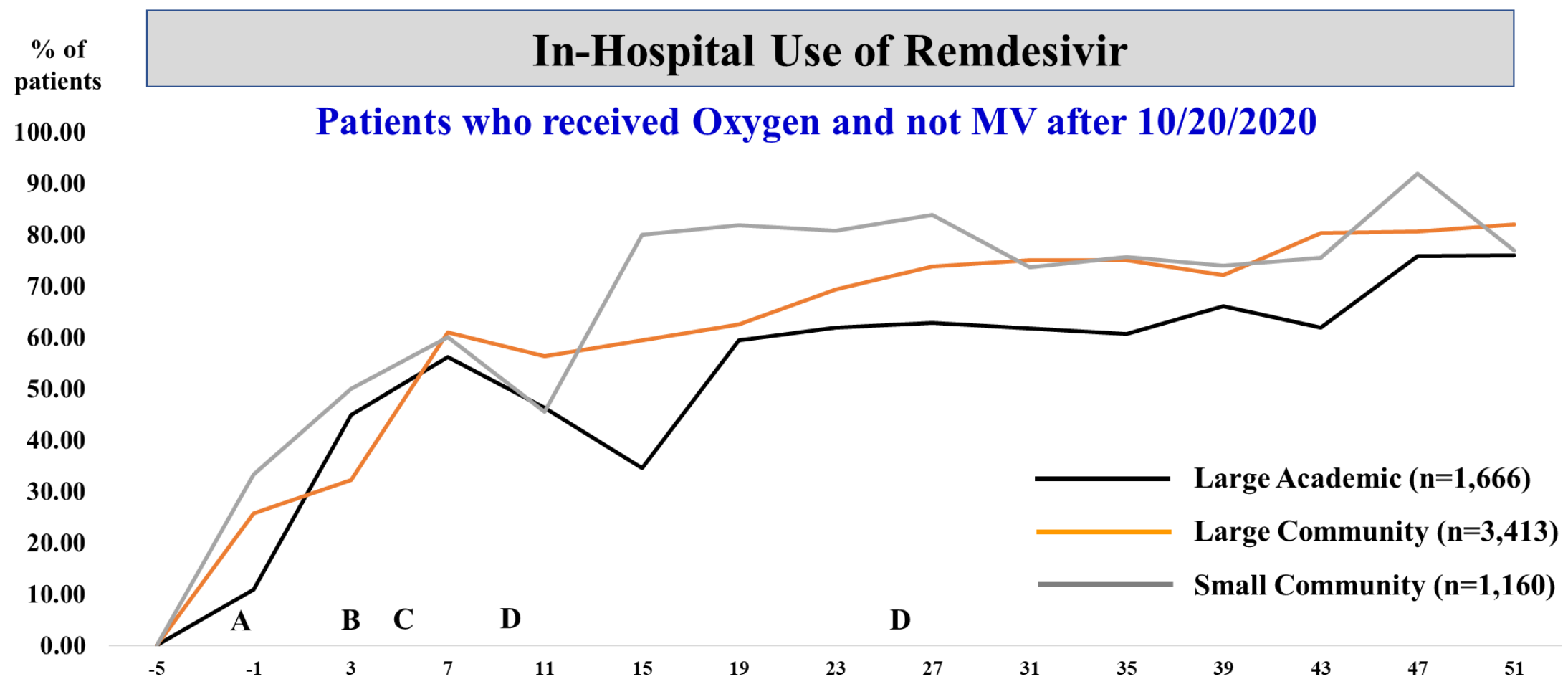
A. $(5 / 1 / 2020)$
FDA issues EUA for Remdesivir for people hospitalized with severe COVID-19 11
B. $(5 / 15 / 2020)$
UPMC receives first shipment of Remdesivir and begins lottery system (5/18) due to limited supply
C. $(6 / 1 / 2020)$
Gilead announces results from Phase 3 trial of Remdesivir ${ }^{12}$
D. $(6 / 29 / 2020)$
U.S. government announces purchase of $>90 \%$ of Remdesivir that Gilead will produce (summer, 2020) ${ }^{13}$
E. $(10 / 22 / 2020)$
FDA approves Remdesivir as the first COVID-19 drug ${ }^{14}$

Supplemental Figure S3 

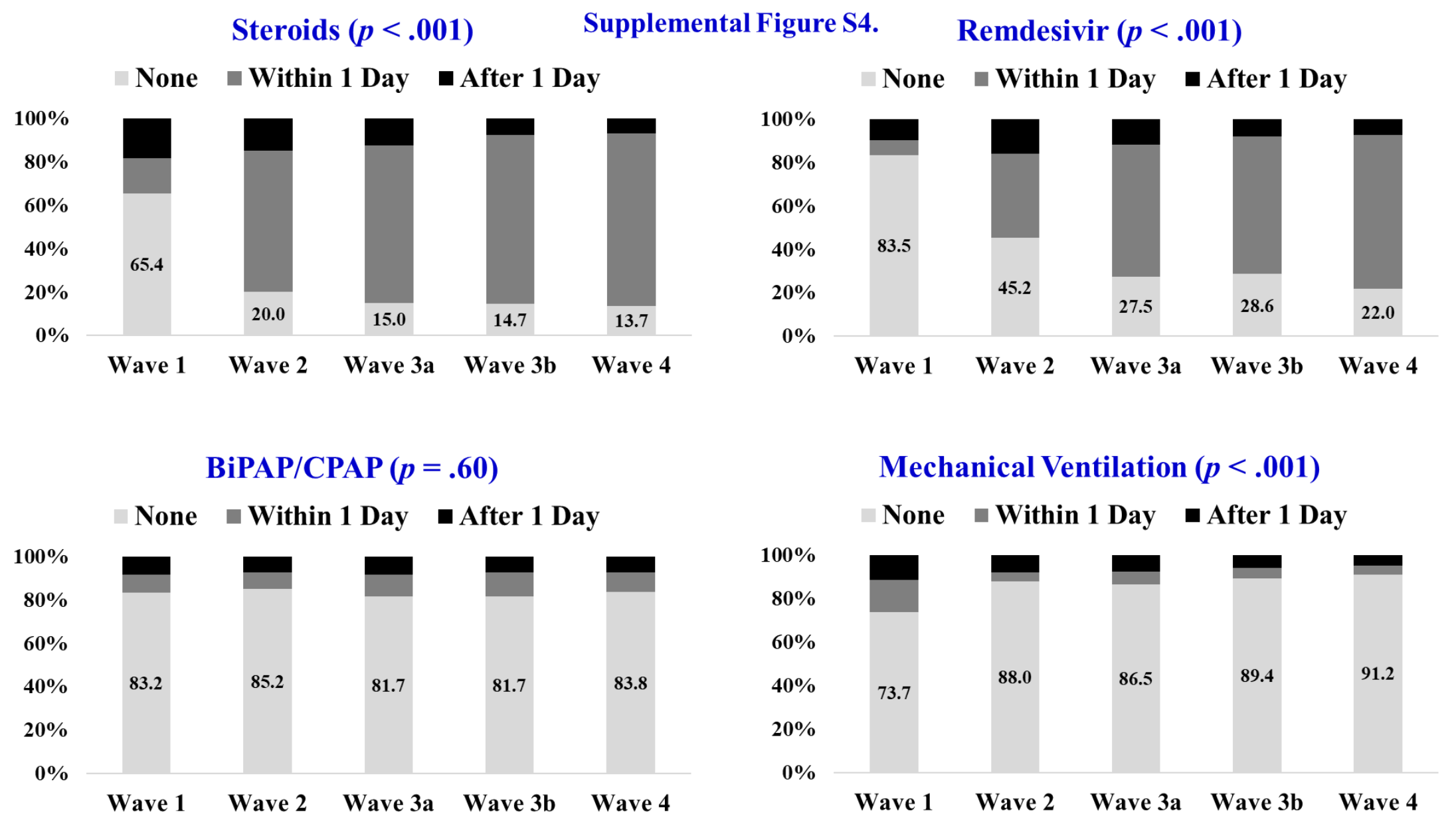